\title{
Nanobiosensors for Pathogenic Agents Detection
}

\author{
Mayra Beltrán-Pineda, ${ }^{a, b}$ Diana Peña-Solórzano ${ }^{\circledR b}$ and César Augusto Sierra ${ }^{*, b}$ \\ ${ }^{a}$ Doctorado en Biotecnología, Facultad de Ciencias, Universidad Nacional de Colombia, \\ Sede Bogotá, Carrera 45 26-85, A.A 5997, Bogotá, Colombia \\ ${ }^{b}$ Grupo de Investigación en Macromoléculas, Departamento de Química, \\ Universidad Nacional de Colombia, Sede Bogotá, Carrera 45 26-85, A.A 5997, Bogotá, Colombia
}

\begin{abstract}
Conventional methods to detect pathogenic microorganisms can be wasteful, expensive, and not very sensitive. Due to these limitations, approaches based on nanotechnology and the development of new diagnostic tests are emerging as alternative methods. Resulting from the unique electrical, magnetic, luminescent, and catalytic properties of nanomaterials, rapid and cost-effective diagnostic tests have been developed to recognize the presence of microbial pathogens or some of their components in different samples. The purpose of this review is to provide an overview and an update regarding the use of several nanomaterials as biosensors, among which are gold nanoparticles, carbon nanotubes, magnetic nanoparticles, and quantum dots. The application of these biosensors has opened a new interdisciplinary frontier between biological detection and materials science.
\end{abstract}

Keywords: pathogens, nanomaterials, nanobiosensors

\section{Introduction}

Pathogens are responsible for the death of a large number of people in both rural and urban settings. Unfortunately, the inaccurate diagnosis of their presence leads to improper handling of its consequences. Additionally, pathogen detection is based on methods that require extended analysis time and are limited by laboratory-based setups, such as microscopy and culture-based techniques, making them even more unsuitable for field application. Therefore, it is necessary to develop highly efficient pathogen detection systems, that are easy to use, low cost, and easy to implement. ${ }^{1}$

Conventional methods for the identification and detection of pathogens (Table 1) are primarily based on (i) culture and colony counting methodologies (involving the counting of bacteria); (ii) immunology-based methods (including antigen-antibody interactions); and (iii) the polymerase chain reaction (PCR) procedure (involving deoxyribonucleic acid (DNA) analysis). However, there are some limitations given that culture-dependent methods are costly. Additionally, pathogens in the sample being analyzed are present in very low concentrations, making their detection very difficult. Besides, a requirement of most

*e-mail: casierraa@unal.edu.co of these detection methods is knowledge of the structural and biochemical properties of the bacterial species, limiting the application of these techniques when the pathogen is unknown. .-11 $^{-11}$

The development of immunoassays as a sensitive method for detecting microorganisms shows some disadvantages due to the use of antibodies that are easily denatured. On the other hand, molecular approaches for the detection of markers associated with the virulence of the pathogen provide satisfactory results but require instrumentation and trained personnel, and such analyses cannot be executed at the field level.,12 Therefore, new analysis techniques have been developed involving biosensors as detection tools that, due to the incorporation of nanomaterials, have increased sensitivity, sample performance, specificity, and limits of detection of the assay, reducing both its complexity and cost. ${ }^{4}$

The benefits of using nanomaterials for biosensor applications are remarkable. Due to their size, quantum confinement effects, reactivity, magnetic properties, electrical properties, and optical properties, nanomaterials, when incorporated into biosensors, can substantially increase the sensitivity of detections. ${ }^{13}$ The use of nanomaterials in transducers leads to the generation of large surface areas, making possible their functionalization with various biomolecules such as nucleic acids, toxins, or proteins. As a consequence, the number of available sites 
Table 1. Current methods for pathogen detection

\begin{tabular}{|c|c|c|c|c|c|}
\hline Technique & Basis & $\begin{array}{l}\text { Limit of detection / } \\
\quad\left(\mathrm{CFU} \mathrm{mL} \mathrm{mL}^{-1}\right)\end{array}$ & Advantages & Disadvantages & Reference \\
\hline $\begin{array}{l}\text { Polymerase chain } \\
\text { reaction }(\mathrm{PCR})\end{array}$ & $\begin{array}{l}\text { enzymatic amplification in vitro of a } \\
\text { DNA fragment, carried out using two } \\
\text { flanking oligonucleotides at the two } \\
\text { ends of the target called primers DNA }\end{array}$ & $10^{3}-10^{4}$ & $\begin{array}{c}\text { standardized } \\
\text { technology, easy } \\
\text { operation }\end{array}$ & $\begin{array}{l}\text { the effectiveness depends } \\
\text { on the DNA extraction } \\
\text { process, presence of } \\
\text { inhibitors, polymerase } \\
\text { activity, the concentration } \\
\text { of the buffer and of DNTP }\end{array}$ & 2,3 \\
\hline $\begin{array}{l}\text { Fluorescent in situ } \\
\text { hybridization (FISH) }\end{array}$ & $\begin{array}{c}\text { hybridization of a DNA probe to its } \\
\text { complementary sequence in previously } \\
\text { fixed preparations; } \\
\text { the probes are directly labeled with } \\
\text { fluorescent nucleotides or indirectly by } \\
\text { molecules that are subsequently detected } \\
\text { by fluorescent antibodies; } \\
\text { finally, the probes and target sequences } \\
\text { are detected and visualized in situ } \\
\text { through microscopic analysis }\end{array}$ & $10^{3}$ & high sensitivity & $\begin{array}{c}\text { autofluorescence, } \\
\text { photochemical destruction } \\
\text { of the fluorophore }\end{array}$ & 3,4 \\
\hline $\begin{array}{l}\text { Enzyme-linked } \\
\text { immunoassay (ELISA) }\end{array}$ & $\begin{array}{l}\text { detection with enzymes of antigen- } \\
\text { antibody binding; } \\
\text { the enzyme converts a non-colored } \\
\text { substrate into a colored product as an } \\
\text { indicator of the binding event }\end{array}$ & $10^{5}-10^{6}$ & $\begin{array}{l}\text { low cost, the color } \\
\text { change is used for } \\
\text { detection }\end{array}$ & $\begin{array}{l}\text { low sensitivity to detect } \\
\text { bacteria }\end{array}$ & 3,5 \\
\hline Immunofluorescence (IF) & $\begin{array}{l}\text { detection of the presence of antibodies } \\
\text { bound to antigens in tissues or body } \\
\text { fluids, involving the emission of light } \\
\text { from a substance that has been irradiated } \\
\text { with a specific wavelength }\end{array}$ & $10^{3}$ & high sensitivity & $\begin{array}{c}\text { photochemical destruction } \\
\text { of the fluorophore }\end{array}$ & 3,6 \\
\hline Flow cytometry (CMF) & $\begin{array}{l}\text { a technique that allows the analysis } \\
\text { of individual cells marked with } \\
\text { fluorochromes, in which the detection } \\
\text { mechanism involves light refraction }\end{array}$ & $10^{4}$ & $\begin{array}{c}\text { simultaneous } \\
\text { measurements of } \\
\text { several parameters, } \\
\text { fast detection }\end{array}$ & high price & 3,7 \\
\hline $\begin{array}{l}\text { Loop-mediated } \\
\text { isothermal amplification } \\
\text { (LAMP) }\end{array}$ & $\begin{array}{l}\text { the reaction mixture is incubated at a } \\
\text { specific temperature using a single tube } \\
\text { containing a buffer, target DNA, DNA } \\
\text { polymerase, and primers; } \\
\text { the detection of the amplified product } \\
\text { occurs by the presence of a precipitate }\end{array}$ & $10^{7}-10^{8}$ & $\begin{array}{l}\text { simple, easy to } \\
\text { use, and rapid, } \\
\text { performed } \\
\text { at a constant } \\
\text { temperature }\end{array}$ & $\begin{array}{l}\text { complicated primer design; } \\
\text { restricted availability of } \\
\text { reagents and equipment in } \\
\text { some countries; } \\
\text { limitations for multiplexing }\end{array}$ & 8 \\
\hline
\end{tabular}

CFU: colony-forming unit; DNA: deoxyribonucleic acid; DNTP: deoxyribonucleotides triphosphate.

for the reaction with the target molecule increases..$^{10}$ Also, the excellent optical, catalytic, magnetic, and electronic properties of nanomaterials facilitate their use in the manufacturing of nanobiosensors with high sensitivity and faster response times as compared to conventional methods. ${ }^{12}$

The two main challenges for detecting a single bacterial cell are rapid real-time detection and ultrasensitivity in the analysis. Due to the significant developments in the last few decades, nanobiosensors are now considered as practical alternatives to the conventional methods for pathogen detection. ${ }^{14}$ Furthermore, advances in pathogen detection could reduce unnecessary drug use and prevent the spread of diseases. ${ }^{11}$ That being said, this review aims to present the characteristics of the nanomaterials used for the development of nanobiosensors and the usefulness of these instruments to detect pathogenic microorganisms.

\section{Nanomaterials}

Nanomaterials are defined as those materials with sizes less than $100 \mathrm{~nm}$ in one of their dimensions. ${ }^{15}$ Characterized by a large surface area per unit mass and several orders of magnitude larger than macroscopic materials, nanomaterials play a fundamental role in both present and future technologies. ${ }^{16}$ Several nanomaterials properties are due to the atomic and molecular constitution of their surfaces, chemical composition, wettability, and electrical charge. ${ }^{17}$ Some examples of nanomaterials used in the manufacture of nanosensors are presented in Table 2.

In nanomaterials, the physicochemical and photophysical properties such as molecular weight, purity, stability, solubility, and catalytic activity rely on their size/shape relationship. Interestingly, many nanomaterial properties can be modified by manipulating the parameters 
Table 2. Characteristics of some nanomaterials used in the manufacture of nanobiosensors

\begin{tabular}{|c|c|c|}
\hline Name & Definition & Characteristics \\
\hline $\begin{array}{l}\text { Gold nanoparticles } \\
\text { (AuNPs) } \\
+4\end{array}$ & $\begin{array}{l}\text { metallic nanoparticles } \\
\text { with an affinity for } \\
\text { sulfhydryl groups with } \\
\text { which covalent bonds } \\
\text { may be established }\end{array}$ & $\begin{array}{c}\text { various shapes: spheres, cubes, } \\
\text { hexagons, or bars; } \\
\text { ability to scatter light; } \\
\text { fluorescents: color change from } \\
\text { blue to red; } \\
\text { chemically stable; } \\
\text { good aggregation; } \\
\text { excellent conductivity; } \\
\text { zero intrinsic toxicity; } \\
\text { easily functionalized }\end{array}$ \\
\hline
\end{tabular}

Chemical precursors

trisodium citrate $(1 \%)$;

hydrogen tetrachloroaurate(III) trihydrate

aqueous solution $(1 \mathrm{mM})$, sodium citrate

$\left(38.8 \mathrm{mmol} \mathrm{L}^{-1}\right)$;

chloroauric acid $\left(0.10 \mathrm{~mol} \mathrm{~L}^{-1}\right)$ aqueous solution;

chloroauric acid $\left(250 \mu \mathrm{mol} \mathrm{L}^{-1}\right)$,

CTAB (100 $\left.\mathrm{mmol} \mathrm{L}^{-1}\right)$ and ascorbic acid $\left(100 \mathrm{~mol} \mathrm{~L}^{-1}\right)$;

dextran solution $(1 \%)$ and chloroauric acid $\left(0.01 \mathrm{~mol} \mathrm{~L}^{-1}\right)$;

polydimethylsiloxane (PDMS), and hydrogen tetrachloroaurate(III) $1 \%$; gold(III) chloride trihydrate solution (1\%), and trisodium citrate solution (1\%)

silver nitrate $\left(0.12 \mathrm{mmol} \mathrm{L}^{-1}\right)$ and

hydroxylamine hydrochloride

$\left(0.17 \mathrm{mmol} \mathrm{L}^{-1}\right)$;

Silver nanoparticles (AgNPs)

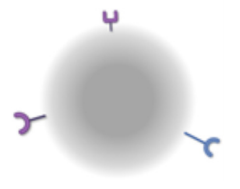

metallic nanoparticles with sizes between 5 and $10 \mathrm{~nm}$ different forms: spheres, bars or triangles;

compared with the great majority of organic and inorganic chromophores, AgNPs have more efficient interaction with visible light silver nitrate $\left(0.018 \mathrm{~mol} \mathrm{~L}^{-1}\right)$, trisodium citrate $\left(0.017 \mathrm{~mol} \mathrm{~L}^{-1}\right)$ and sodium borohydride $(0.01 \mathrm{M})$;

dry leaf extract, and silver nitrate $\left(100 \mathrm{mmol} \mathrm{L}^{-1}\right)$;

silver nitrate $\left(5 \times 10^{-3} \mathrm{~mol} \mathrm{~L}^{-1}\right)$, sodium

borohydride $\left(2 \times 10^{-3} \mathrm{~mol} \mathrm{~L}^{-1}\right)$, and poly (vinyl alcohol) $1 \%$;

aqueous extract of Padina sp., and aqueous silver nitrate $\left(0.01 \mathrm{~mol} \mathrm{~L}^{-1}\right)$

TEOS and ammonium hydroxide; TEOS and ammonia solution (25 wt.\%); 3-amino propyltrimethoxysilane, tetraethyl orthosilicate $\left(1 \mathrm{~mol} \mathrm{~L}^{-1}\right)$, and ammonium hydroxide;

cyclohexane, hexyl alcohol, Triton X-100,

a silica matrix and

characterized by

pores with a diameter

between 2 and $50 \mathrm{~nm}$ elevated surface area; modifiable pore volume; mechanical strength; chemical and thermal stability; biocompatibility; non-toxic;

biodegradable; inert water, and TEOS;

L-arginine water solution $\left(6 \mathrm{mmol} \mathrm{L}^{-1}\right)$,

TEOS, $\mathrm{SiO}_{2}$, ethanol, and ammonium hydroxide

ferric chloride $\left(\mathrm{FeCl}_{3}, 4 \mathrm{mmol}\right)$, urea

Magnetic nanoparticles (MNPs)

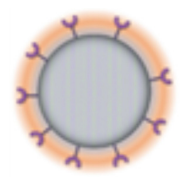

iron oxide particles composed of a magnetite core biocompatibility. easily biodegradable; functionalizable with amino and carboxyl groups; used to separate or enrich a target analyte
$(12 \mathrm{mmol})$, sodium citrate $(8 \mathrm{mmol})$ and polyacrylamide $(0.6 \mathrm{~g})$;

ferric chloride $\left(\mathrm{FeCl}_{3}\right)$, iron(II) chloride

$\left(\mathrm{FeCl}_{2}\right)$ and aqueous hydrochloric acid $\left(\mathrm{HCl}, 2 \mathrm{~mol} \mathrm{~L}^{-1}\right)$;

$10,12,27,28$

ferric chloride $\left(\mathrm{FeCl}_{3}, 1 \mathrm{~mol} \mathrm{~L}^{-1}\right)$, iron sulfate (II) $\left(\mathrm{FeSO}_{4}, 1 \mathrm{~mol} \mathrm{~L}^{-1}\right)$ and aqueous hydrochloric acid $\left(\mathrm{HCl}, 2 \mathrm{~mol} \mathrm{~L}^{-1}\right)$; iron(III) acetylacetonate and benzyl alcohol

cadmium oxide $\left(0.2 \mathrm{~mol} \mathrm{~L}^{-1}\right)$, selenium

$\left(2 \mathrm{mmol} \mathrm{L}^{-1}\right)$, sulfur solution

(0.04 $\left.\mathrm{mol} \mathrm{L}^{-1}\right)$, trioctylphosphine oxide

$(0.5 \mathrm{~g})$, tributylphosphine $(0.472 \mathrm{~g})$,

1-octadecene ( $2 \mathrm{~g})$, oleic acid (1.5 g),

octadecylamine $(1.5 \mathrm{~g})$ and stearic acid $\left(0.8 \mathrm{mmol} \mathrm{L}^{-1}\right)$;

$10,12,28,29$

by coating with an organic material layer, surface functionalization for the binding of biomolecules is achieved; bright with high photostability cadmium selenide (CdSe) nanocrystals, and zinc sulfide ( $\mathrm{ZnS})$;

mercaptoacetic acid liquid, aqueous $\mathrm{CdCl}_{2}$ (0.01 $\left.\mathrm{mol} \mathrm{L}^{-1}\right)$, aqueous $\mathrm{Na}_{2} \mathrm{~S}\left(5 \mathrm{mmol} \mathrm{L}^{-1}\right)$, and chlorophyll 
Table 2. Characteristics of some nanomaterials used in the manufacture of nanobiosensors (cont.)

\begin{tabular}{|c|c|c|c|c|}
\hline Name & Definition & Characteristics & Chemical precursors & Reference \\
\hline 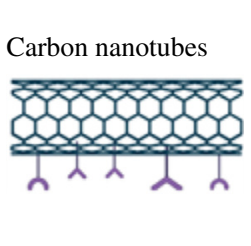 & $\begin{array}{c}\text { monoatomic layers of } \\
\text { carbon atoms perfectly } \\
\text { aligned and arranged } \\
\text { in beehive structures } \\
\text { wound in a cylindrical } \\
\text { tube or several coupled } \\
\text { tubes }\end{array}$ & $\begin{array}{l}\text { sizes between } 1 \mathrm{~nm} \text { to a few } \\
\text { microns or more; } \\
\text { photoluminescent; } \\
\text { semiconductors: excellent } \\
\text { electrical properties; } \\
\text { work as signal amplifiers and } \\
\text { transducers }\end{array}$ & $\begin{array}{l}\text { iron nitrate in isopropanol, } 500 \mathrm{~nm} \text { layer of } \\
\text { silicon dioxide; } \\
\text { graphite flakes, sulfuric acid, sodium nitrite, } \\
\text { sodium permanganate, and deionized water; } \\
\text { SWCNTs in DMF }\end{array}$ & $10,12,30$ \\
\hline $\begin{array}{l}\text { Metal-organic } \\
\text { frameworks (MOFs) }\end{array}$ & $\begin{array}{l}\text { two- or three- } \\
\text { dimensional } \\
\text { coordination networks } \\
\text { formed by metal } \\
\text { complexes linked to } \\
\text { multifunctional organic } \\
\text { ligands }\end{array}$ & $\begin{array}{l}\text { high surface area; } \\
\text { thermal/mechanical stability; } \\
\text { good optical properties; } \\
\text { resistance to photobleaching }\end{array}$ & $\begin{array}{c}\mathrm{Zn}\left(\mathrm{NO}_{3}\right)_{2} \cdot 6 \mathrm{H}_{2} \mathrm{O}(16 \mathrm{mmol}), 2 \text {-amino } \\
\text { terephthalic acid }(8 \mathrm{mmol}), \mathrm{DMF}(160 \mathrm{~mL}) \\
\text { and trimethylamine }(64 \mathrm{mmol}) ; \\
\mathrm{Cu}\left(\mathrm{NO}_{3}\right)_{2} \cdot 3 \mathrm{H}_{2} \mathrm{O}(0.015 \mathrm{mmol}), \\
\text { trifluoroacetic acid }\left(1.0 \mathrm{~mol} \mathrm{~L}^{-1}\right), \text { and } \\
\text { polyvinylpyrrolidone; } \\
\mathrm{ZrCl}_{4}, \mathrm{DMF} \text {, and } \mathrm{CuCl}_{2} \cdot 2 \mathrm{H}_{2} \mathrm{O}\end{array}$ & 13,31 \\
\hline
\end{tabular}

CTAB: cetyltrimethylammonium bromide; TEOS: tetraethylorthosilicate; DMF: dimethylformamide; SWCNT: single-walled carbon nanotube.

of the synthesis, such as the precursors' temperature and concentration, and through the nanomaterial surface's functionalization..$^{32}$ In the biological environment, properties such as biodistribution, transport, retention at the tissue level, and degradation of the nanomaterial are also determined by its shape and chemical composition, being the charge relevant in the union to receptors and the penetration of physiological barriers. ${ }^{17}$

When nanomaterials are exposed to living systems, they are quickly surrounded by proteins, lipids, and other biomolecules, increasing their biocompatibility. This is a determining factor in bioapplications, since it avoids nanoparticle detection as a foreign element and evades rejection by natural defense systems. This phenomenon is known as the formation of the bio-crown, which gives a new biological identity as their surface changes. ${ }^{33}$

\section{Nanobiosensors for Pathogenic Agents Detection}

Biosensors were reported for the first time in the 1960s; since then, they have been used mainly in environmental monitoring and biological detection. ${ }^{34}$ As analytical instruments, biosensors combine biological recognition, transforming this phenomenon into digital signals that are interpreted through software. ${ }^{35}$ Depending on the operating principle of the biosensor, the substance of interest present in living or non-living systems, the analyte, can be sensed by taking advantage of some of its properties (electrical, chemical, electrochemical, optical, magnetic, or vibratory, Table 2). ${ }^{3}$

Generally, these devices are made up of a biorecognition unit or bioreceptor and a transducer (Figure 1). The analyte-bioreceptor interaction will produce an effect measurable by the transducer, generating, for example, an electronic signal. ${ }^{34}$ This is achieved by the immobilization of the biorecognition elements through encapsulation, covalent interaction, adsorption, or a combination of these. ${ }^{3,36}$ These biorecognition units, or bioreceptors, present in cells (such as glycoproteins, glycopeptides, lipoproteins, carbohydrates, lipids, and receptor proteins) fulfill multiple functions, participating in infection processes, adhesion to cell surfaces and non-cellular substrates, evasion of the immune system, nutrient intake and transport thereof. Since they are exposed to the extracellular environment, bioreceptors have one feature in common; they serve as biorecognition elements during the bisosensors' assembly. ${ }^{12}$

By using nanomaterials in their construction, the limit of detection of biosensors is greatly improved. This is attributed to their large surface area, high electronic conductivity, and plasmonic properties, such as the ability to store light in confined spaces. ${ }^{3,36}$ Additionally, nanomaterials as biosensors allow the use of new optical or mechanical signals, mainly as transduction methods. ${ }^{36}$

As defined above and applied to biosensors, a material with a size below $100 \mathrm{~nm}$ is considered a nanobiosensor. ${ }^{28}$ In these, the fundamentals of spectroscopy, optics, and mechanics, among others, are used as the operating principle (Table 3). These dimensions imply that nanobiosensors, due to the small area available for detection, demand less analyte to register a measurable response. Smaller spaces generally allow higher density arrays, which maximize the number of analytes detected in a single test. Additionally, the complexity of the pathogen detection tests and their costs can be reduced by using nanobiosensors through eliminating some of the 


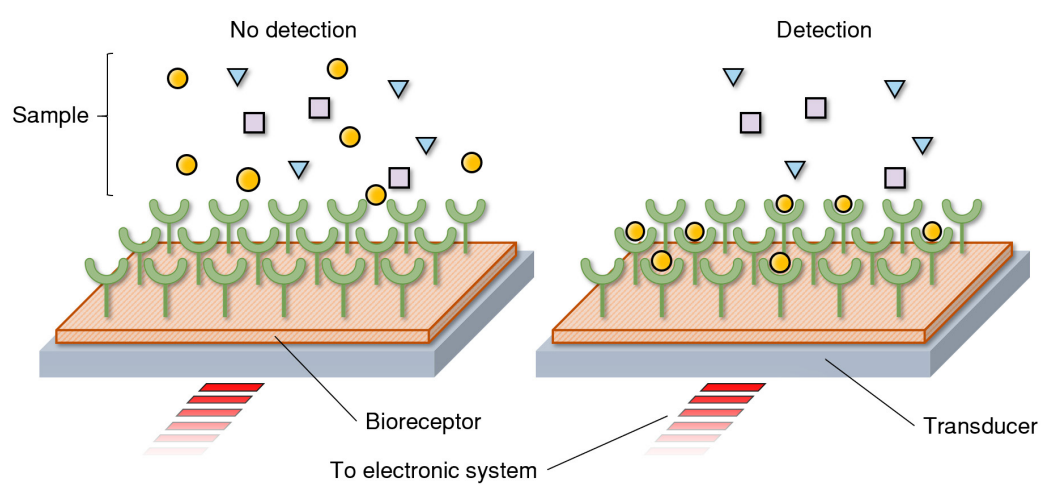

Figure 1. Scheme of a conventional biosensor. The device is made up of a bioreceptor, a transducer, and an electronic system that allows the detection of the analyte of interest (yellow sphere) when it comes into contact with a sample that contains it.

sample processing stages normally present in conventional methods, such as DNA amplification or fluorochrome staining. ${ }^{11}$

Generally, nanobiosensors are based on the interaction between nucleic acids, enzymes-substrate, cells-bacteria, or antigen-antibody interactions, using biomimetic materials that replicate biological processes and materials such as synthetic bioreceptors (Figure 2). ${ }^{12,34,44}$ Several pathogens have been detected using these interactions, especially in vitro, and on different food samples such as milk and drinking water (Table 4). Escherichia coli stands out as the most studied target bacteria using nanobiosensors devices.

\subsection{Biosensors with gold nanoparticles (AuNPs)}

AuNPs as biosensors are very attractive, mainly due to their high electrical conductivity that allows them to transfer electrons easily. ${ }^{3}$ Other benefits include their efficient optical properties and facile surface functionalization. This has led to their widespread use in biological detection processes such as DNA hybridization and DNA-protein interactions. ${ }^{90}$ These features, and the fact that the surface of AuNPs displays an excellent affinity for sulfhydryl groups (-SH), allow the nanoparticles' functionalization by conjugating them with molecules or polymers containing these functional groups through covalent bonds. This facilitates their application in several tests using antibodies and nucleic acids. ${ }^{12}$ Moreover, the fluorescence in AuNPs has been used in quenching processes, where one side of the nanoparticle has oligonucleotide molecules marked with a sulfhydryl group, while the other end is attached to a fluorophore. For example, optical biosensors for specific DNA sequences show an increase in the deactivated fluorophore's fluorescence after the biosensor-analyte

Table 3. Main types of nanobiosensors and operating principles

Operating principle
using SRP (surface plasmon resonance) as a direct means to measure the
binding of a target molecule to a surface ligand, light is reflected from the
detection surface when binding events occur;


Table 3. Main types of nanobiosensors and operating principles (cont.)

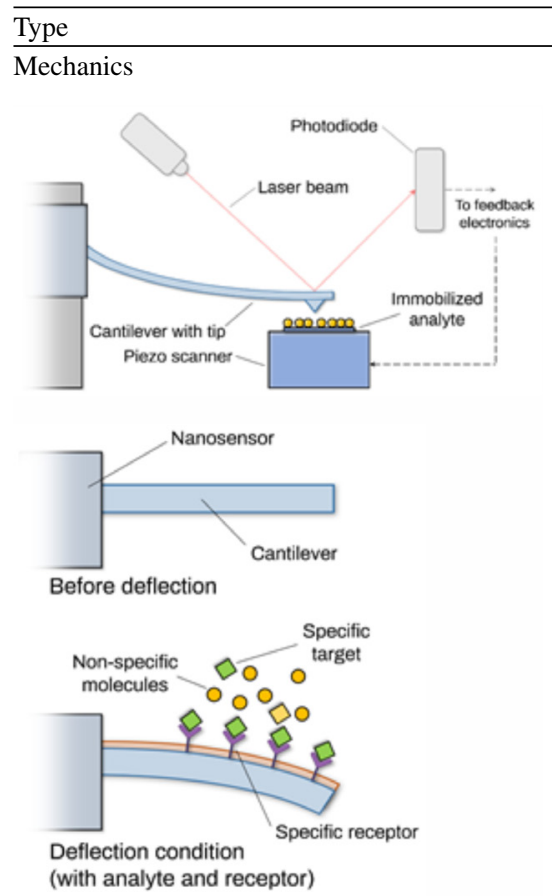

Operating principle Reference

Mechanics

with analyte and receptor)

Adapted from Driskell and Tripp. ${ }^{11}$ DNA: deoxyribonucleic acid.

(a)

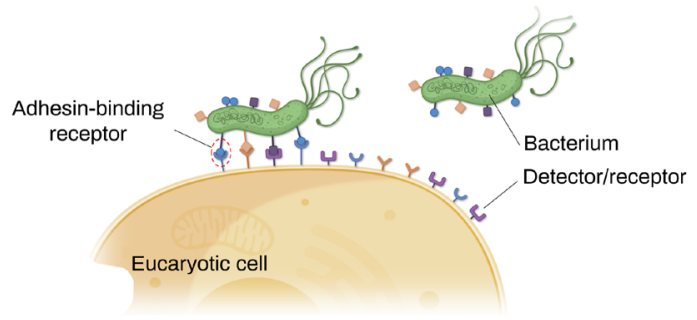

(b)

(d)
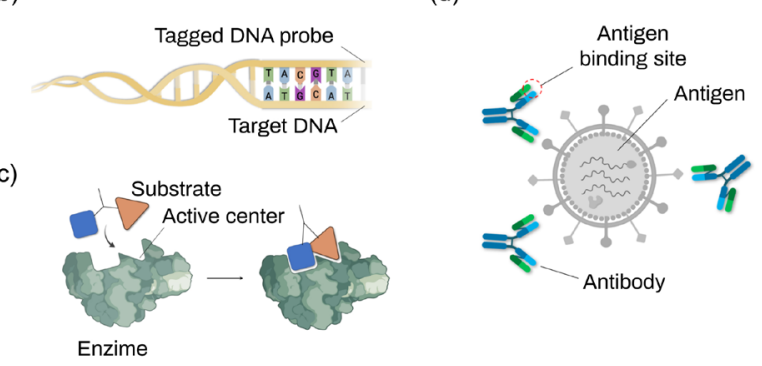

(e)

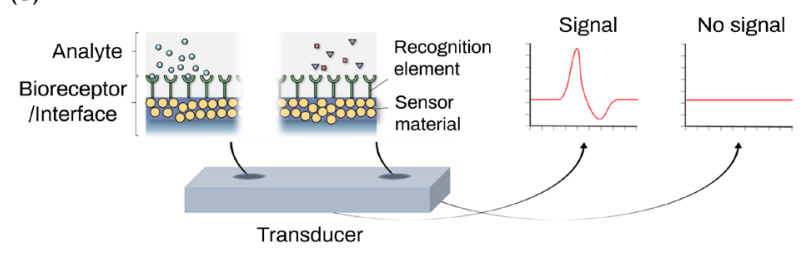

Figure 2. Biological and non-biological interactions using for the design of biosensors: (a) cell interactions, (b) interaction between nucleic acids, (c) enzymatic interactions, (d) antigen-antibody association, and (e) interactions using biomimetic materials.
Table 4. Some pathogenic agents detected by nanobiosensors

\begin{tabular}{lc}
\hline Bacterial species & Reference \\
\hline Escherichia coli & $14,19,26,43,44,57-70$ \\
Staphylococcus aureus & $71-73$ \\
Staphylococcus saprophyticus & 18 \\
Mycobacterium tuberculosis & 74 \\
Salmonella typhimurium & $75-80$ \\
Brucella abortus & 56 \\
Salmonella sp. & $41,59,77,80$ \\
Salmonella enterica & $23,38,45,81$ \\
Pseudomonas aeruginosa & $38,39,82-84$ \\
Bacillus subtilis & $49,61,85$ \\
Bacillus cereus & 59,86 \\
Candida albicans & 87 \\
Enterococcus faecalis & 62 \\
Vibrio cholerae & 27,88 \\
Cryptosporidium parvum & 89 \\
Giardia lamblia & 89 \\
\hline
\end{tabular}

interaction due to a conformational change in the system (Table 5). ${ }^{36}$ In 2008, Nath et al. ${ }^{19}$ used AuNPs functionalized with dextran to detect $E$. coli in three hours, in the absence of carbohydrate intake by $E$. coli or sterile conditions. The presence of free carbohydrates can be detected by the addition of concanavalin $\mathrm{A}$, which produces a change in the 
plasmon band due to nanostructure formation (Figure 3). However, DNA-based biosensors have the disadvantage of requiring isolation of the microorganism, cell lysis, and bacterial DNA extraction, limiting its application as a diagnostic technique at the field level in developing countries. ${ }^{12}$

Table 5. Gold nanobiosensors used for pathogenic agent detection

\begin{tabular}{|c|c|c|c|c|c|}
\hline $\begin{array}{l}\text { Functionalized } \\
\text { substances }\end{array}$ & $\begin{array}{c}\text { Pathogens or analyte to } \\
\text { detect }\end{array}$ & Operating principle & $\begin{array}{l}\text { Limit of } \\
\text { detection }\end{array}$ & $\begin{array}{l}\text { Detection } \\
\text { time / h }\end{array}$ & Reference \\
\hline $\begin{array}{l}\text { Antibody } \\
\text { immunoglobuline } G \\
(\operatorname{IgG}) \text { anti-SEB }\end{array}$ & $\begin{array}{l}\text { enterotoxin B from } \\
\text { Staphylococcus aureus }\end{array}$ & $\begin{array}{l}\text { on this lamella specific antibodies (anti-SEB } \\
\text { IgG) are functionalized, binding to the protein's } \\
\text { carboxyl group; } \\
\text { after contact with the analyte, the affinity } \\
\text { interaction takes place, but a process of } \\
\text { amplification of the signal is required; for that, } \\
\text { two additional antibodies are used to detect very } \\
\text { low toxin concentrations }\end{array}$ & $10^{-5} \mathrm{~mol}$ & 0.2 & 91 \\
\hline $\begin{array}{l}\text { Immunoglobuline } \mathrm{G} \\
\text { (IgG) }\end{array}$ & $\begin{array}{l}\text { Staphylococcus aureus, } \\
\text { S. saprophyticus }\end{array}$ & $\begin{array}{c}\text { when magnetic nanoparticles functionalized } \\
\text { with IgG are used, dispersed bacterial cells are } \\
\text { selectively concentrated in a solution facilitating } \\
\text { their detection }\end{array}$ & ND & 1 & 18 \\
\hline $\begin{array}{l}\text { Poly(p-phenylene } \\
\text { ethynylene) (PPE) }\end{array}$ & $\begin{array}{l}\text { Amycolatopsis azurea, } \\
\text { Amycolatopsis orientalis } \\
\text { subsp. }\end{array}$ & $\begin{array}{l}\text { the interaction of bacteria with the nanoparticle- } \\
\text { PPE conjugate produces the release of anionic } \\
\text { PPE, which restores fluorescence }\end{array}$ & ND & 0.5 & 45 \\
\hline DNA & Salmonella enterica & $\begin{array}{l}\text { there is an exponential relationship between } \\
\text { the target DNA concentration and the released } \\
\text { barcode DNA's fluorescence signal }\end{array}$ & $1 \mathrm{ng} \mathrm{mL}^{-1}$ & ND & 20 \\
\hline Thiolated RNA probe & Escherichia coli & $\begin{array}{c}\text { carbon nanotubes coated with AuNPs } \\
\text { functionalized with a thiolated RNA probe- } \\
\text { specific (aptamers) can bind efficiently to } \\
\text { Escherichia coli, which is evidenced by a change } \\
\text { in absorbance }\end{array}$ & ND & 0.3 & 60 \\
\hline $\begin{array}{l}\text { Paracetamol dimer } \\
(\mathrm{PD})\end{array}$ & $\begin{array}{c}\text { Pediococcus acidilactici } \\
\text { Bacillus cereus }\end{array}$ & $\begin{array}{c}\text { fluorescent nanocomposite, consisting of } \\
\text { paracetamol dimer (PD) and AuNPs, successfully } \\
\text { detects six bacterial strains; the Gram-positive } \\
\text { and Gram-negative bacteria quench the } \\
\text { fluorescence }\end{array}$ & $100 \mathrm{CFU} \mathrm{mL}^{-1}$ & 12 & 21 \\
\hline DNA & $\begin{array}{c}\text { Escherichia coli } \\
\text { O157:H7 }\end{array}$ & $\begin{array}{l}\text { a fluorescence "on/off" switch to detect } E \text {. coli } \\
\text { O157:H7 was created, the stem-loop DNA probe } \\
\text { reached the maximum fluorescence intensity } \\
\text { value when there was } 10 \mathrm{~nm} \text { between Cy3 and } \\
\text { the surface of the Au@ } \mathrm{Ag} \text { nanorods }\end{array}$ & $\begin{array}{l}3.33 \times 10^{-18} \\
\mathrm{~mol} \mathrm{~L}^{-1}\end{array}$ & 7 & 86 \\
\hline СТАВ & $\begin{array}{l}\text { Staphylococcus aureus, } \\
\text { Escherichia coli, } \\
\text { Salmonella enterica }\end{array}$ & $\begin{array}{c}\text { the positively charged AuNPs bind to the } \\
\text { negatively charged enzyme } \beta \text {-galactosidase } \\
\text { causing its deactivation; } \\
\text { the color change of the solution evidences the } \\
\text { binding due to the enzymatic decomposition } \\
\text { of the fluorogenic chlorophenol red } \\
\beta \text {-D-galactopyranoside }\end{array}$ & $10 \mathrm{CFU} \mathrm{mL}^{-1}$ & 1 & 23 \\
\hline $\begin{array}{l}\text { Thiolated protein } \mathrm{G} \\
\text { (PrG-thiol) }\end{array}$ & $\begin{array}{c}\text { Escherichia coli } \\
\text { O157:H7 }\end{array}$ & $\begin{array}{l}\text { PrG is commonly used to immobilize antibodies } \\
\text { on solid supports; } \\
\text { when binding to immunoglobulin } \mathrm{G}(\mathrm{IgG}), \mathrm{PrG} \\
\text { leaves fragments of the antigen (Fab) aligned and } \\
\text { with little steric hindrance, facilitating detection }\end{array}$ & $48 \mathrm{CFU} \mathrm{mL}^{-1}$ & 8 & 92 \\
\hline $\begin{array}{l}\text { Solid-phase isothermal } \\
\text { recombinase polymerase } \\
\text { amplification (RPA) }\end{array}$ & $\begin{array}{l}\text { Citrus tristeza virus } \\
\text { (CTV) }\end{array}$ & $\begin{array}{c}\text { the CTV target amplified in situ was investigated } \\
\text { by EIS in a redox system using an optimized } \\
\text { RPA that includes an AuNP-modified electrode } \\
\text { with a thiolated primer }\end{array}$ & $1000 \mathrm{fg} \mathrm{mL}^{-1}$ & 2 & 93 \\
\hline $\begin{array}{l}\text { 4-Mercaptobenzoic } \\
\text { acid }\end{array}$ & Vibrio parahaemolyticus & $\begin{array}{l}\text { detection measured by the decrease in the Raman } \\
\text { signal at } 1592 \mathrm{~cm}^{-1} \text {, due to the electrostatic } \\
\text { interaction between a negatively charged } \\
\text { signaling probe ( } 4 \text {-mercaptobenzoic acid bound } \\
\text { to AuNP modified with aptamers) and cysteamine }\end{array}$ & $12 \mathrm{CFU} \mathrm{mL}^{-1}$ & 0.8 & 82 \\
\hline
\end{tabular}


Table 5. Gold nanobiosensors used for pathogenic agent detection (cont.)

\begin{tabular}{|c|c|c|c|c|c|}
\hline $\begin{array}{l}\text { Functionalized } \\
\text { substances }\end{array}$ & $\begin{array}{c}\text { Pathogens or analyte to } \\
\text { detect }\end{array}$ & Operating principle & $\begin{array}{l}\text { Limit of } \\
\text { detection }\end{array}$ & $\begin{array}{c}\text { Detection } \\
\text { time / h }\end{array}$ & Reference \\
\hline $\begin{array}{l}\text { Azide and alkyne } \\
\text { functional molecules }\end{array}$ & Escherichia coli & $\begin{array}{l}\text { possible by using the click reaction between } \\
\text { modified AuNPs and azide and alkyne functional } \\
\text { molecules, catalyzed by } \mathrm{Cu}^{+} \text {, producing in the } \\
\text { solution a change from red to blue due to the } \\
\text { aggregation of nanoparticles }\end{array}$ & $40 \mathrm{CFU} \mathrm{mL}^{-1}$ & 1 & 52 \\
\hline $\begin{array}{l}\text { Fullerene nanoparticles/ } \\
\text { nitrogen-doped graphene } \\
\text { (nano-C60/NGS) }\end{array}$ & $\begin{array}{l}\text { Mycobacterium } \\
\text { tuberculosis }\end{array}$ & $\begin{array}{l}\text { Au-nano-C60/NGS acting as a new signal tag } \\
\text { produce a response in the absence of redox } \\
\text { molecules; } \\
\text { subsequently, to achieve signal amplification, it is } \\
\text { labeled with signal probes creating a tracer label }\end{array}$ & $3 \mathrm{fmol} \mathrm{L}^{-1}$ & ND & 94 \\
\hline Polyaniline (PANI) & $\begin{array}{l}\text { Pseudomonas } \\
\text { aeruginosa }\end{array}$ & $\begin{array}{l}\text { the PANI/AuNP prepared show to be a highly } \\
\text { sensitive pyocyanin sensor in a pathogen culture, } \\
\text { which uses electron microscopy and cyclic } \\
\text { voltammetry to study morphology and electrical } \\
\text { conductivity of the constructed electrode }\end{array}$ & $500 \mathrm{nmol} \mathrm{L}^{-1}$ & 24 & 95 \\
\hline Oligonucleotide primers & $\begin{array}{l}\text { Listeria monocytogenes, } \\
\text { S. typhimurium, } \\
\text { Escherichia coli }\end{array}$ & $\begin{array}{l}\text { flower-shaped AuNPs were used as a colorimetric } \\
\text { sensor; the detection of PCR products was visible } \\
\text { to the naked eye by directly mixing them with } \\
\text { FAuNPs and } \mathrm{NaCl}\end{array}$ & $\begin{array}{c}10,10 \text { and } 50 \\
\operatorname{pg~mL}^{-1}\end{array}$ & 0.2 & 96 \\
\hline AuNPs & $\begin{array}{l}\text { Escherichia coli } \\
\text { (MTCC723 and } \\
\text { MTCC443) }\end{array}$ & $\begin{array}{l}\text { the growth of bacteria inhibition by } \mathrm{ZnO}-\mathrm{NPs} \text { is } \\
\text { possible using fluorescence microscopy; } \\
\text { due to changes in cell membrane permeability } \\
\text { and intracellular metabolic system }\end{array}$ & ND & ND & 97 \\
\hline $\begin{array}{l}\text { Perfluorodecanethiol } \\
\text { (PFDT) }\end{array}$ & $\mathrm{A} / \mathrm{H} 1 \mathrm{~N} 1$ & $\begin{array}{c}\text { release of Cy3-tagged aptamer DNA from } \\
\text { nanopopcorn substrate surfaces through } \\
\text { interaction between aptamer DNA-A/H1N1 virus } \\
\text { was measured using the decrease in intensity of } \\
\text { the resulting Raman peak }\end{array}$ & $97 \mathrm{PFU} \mathrm{mL}^{-1}$ & 0.3 & 98 \\
\hline
\end{tabular}

IgG: immunoglobuline G; SEB: enterotoxin B from S. aureus; ND: not determined; DNA: deoxyribonucleic acid; RNA: ribonucleic acid; AuNPs: Au nanoparticles; CFU: colony-forming unit; CTAB: cetyltrimethylammonium bromide; EIS: electrochemical impedance spectroscopy; FAuNPs: flowershaped AuNPs; PFU: plaque forming units.

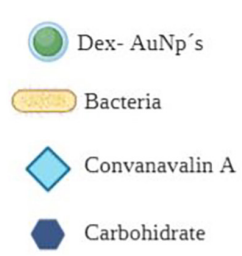

(a)

(b)

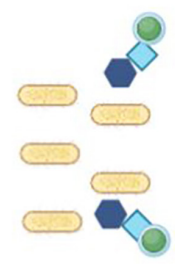

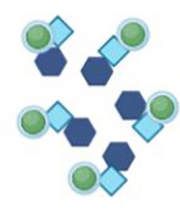

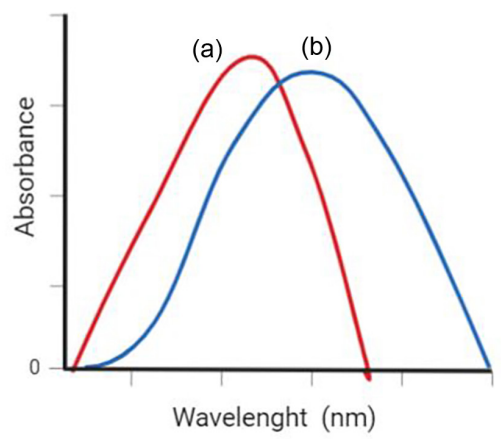

Figure 3. AuNPs nanobiosensor functionalized with dextran. (a) When bacteria are present, the concentration of free carbohydrates decreases and the formation of nanoaggregates also decreases, generating lower changes in the plasmonic band. (b) Under sterile conditions, the addition of concanavalin A allows the formation of nanoaggregates given the presence of free carbohydrates, generating large shifts in the surface plasmon band (adapted from Nath et al. ${ }^{19}$ ).

\subsection{Biosensors with silver nanoparticles (AgNPs)}

Silver has been widely used within the metallic elements to manufacture NPs and has received considerable attention due to its particular physicochemical properties. Among these are the ability to interact with visible light, the presence of a characteristic band of superficial plasmons, and the absence of toxicity to humans and animals. ${ }^{47}$

Silver nanoparticles' unique properties make them highly attractive commercially and scientifically, especially in technologies such as disinfectants, antimicrobials, cryogenic superconductors, composite fibers, cosmetics, electronics, and particularly as biosensors. Among the many methods for synthesizing silver nanoparticles, techniques such as electrochemistry, radiolysis, and chemical reduction stand out. The latter is one of the most widely used synthetic procedures, using a wide variety of inorganic and organic reducing agents. More recently, the synthesis of nanoparticles with an ecological vision has become a fascinating research area. This green chemistry perspective has included the use of mixedvalence polyoxometalates, polysaccharides, irradiation, and the inclusion of methods from biology, which have 
shown advantages over conventional methods that involve chemical agents associated with toxicity (Table 6). ${ }^{24}$

From the spectroscopic point of view, AgNPs have a single absorption band in the UV-Vis range, in contrast to the bulk material. The absorption occurs when the excitation frequency alters the electrons, generating a phenomenon called localized surface plasmon resonance (LSPR). Studies have shown that the absorption wavelength in AgNPs is extremely sensitive to its local refractive index, particle size, and shape. ${ }^{11}$ Since the resonance band of the surface plasmons is susceptible to several surface-level processes such as the absorption of molecules or nanoparticles' aggregation, AgNPs have shown fascinating results in numerous applications as biosensors. ${ }^{36}$ This, and the ability to functionalize its surface using various biopolymers, have allowed AgNPs to have a high impact on the detection of proteins, antibodies, peptides, and oligonucleotides..$^{12,25}$

Zhou et al..$^{22}$ developed a SERS (surface enhance Raman scattering) based detection technique that uses metal nanoparticles, given the electromagnetic field present on their surface. Raman signals are a spectroscopic fingerprint to monitor microorganisms in vivo, making it possible to detect Escherichia coli and Staphylococcus epidermidis in drinking water. For this, a layer of AgNPs coated with the bacterial cells was synthesized, and then the bacteria were analyzed by SERS. It was found that the intensity of the Raman signals increases after the nanoparticle synthesis, which mainly depends on the zeta potential of the bacterial cell wall. Interestingly, the total time required for the test was only ten minutes, and the sample volume required for the analysis just $1 \mathrm{~mL}$, detecting up to $2.5 \times 10^{2}$ cells per $\mathrm{mL}$. With a very similar approach, Chen et al..$^{74}$ used positively charged silver nanoparticles $\left(\mathrm{AgNPs}^{+}\right)$and Raman scattering as a method for the identification, in one hour, of methicillin-resistant Staphylococcus aureus (Figure 4).

\subsection{Biosensors with silica nanoparticles}

Fluorescent silica nanoparticles (SiNP) have attracted particular attention because of their potential in applications such as generating diagnostic images at the clinical level and the detection of pathogens or ligand-receptor interactions (Table 7). ${ }^{101}$ Also, SiNP can be manufactured in various stable fluorescence colors and are biocompatible.

Like other nanoparticles, SiNP can be functionalized with several chemical groups such as amines, carboxyls, sulfhydryls, and organic compounds such as methacrylate..$^{26}$ Zhao et al. ${ }^{14}$ developed a bioassay based on in situ detection of Escherichia coli O157:H7 using bioconjugated SiNP in a fluorescence-based immunoassay, using antibodies that accurately detect the bacteria. Of note, Escherichia coli $\mathrm{O} 157: \mathrm{H7}$ is one of the agents responsible for transmitting food-borne diseases. The technique showed high effectiveness, identifying from 1 to 400 cells of the

Table 6. Silver nanobiosensors used for pathogenic agent detection

\begin{tabular}{|c|c|c|c|c|c|}
\hline $\begin{array}{l}\text { Functionalized } \\
\text { substance }\end{array}$ & $\begin{array}{c}\text { Pathogens or analyte to } \\
\text { detect }\end{array}$ & Operating principle & Limit of detection & $\begin{array}{c}\text { Detection } \\
\text { time } / \mathrm{h}\end{array}$ & Reference \\
\hline Polyvinylpyrrolidone & $\begin{array}{c}\text { Staphylococcus aureus } \\
\text { Pseudomonas aeruginosa }\end{array}$ & $\begin{array}{l}\text { this biosensor showed that the synthesis } \\
\text { method (microwave or thermal radiation) } \\
\text { and the composition of the plant extract } \\
\text { have a strong influence on the nanoparticles' } \\
\text { activity; } \\
\text { the antioxidant potential of the plant extract } \\
\text { is critical for the antimicrobial activity of NPs } \\
\text { and the reduction method applied to the metal }\end{array}$ & $10 \mu \mathrm{g} \mathrm{mL}^{-1}$ & 24 & 83 \\
\hline Urease & Salmonella & $\begin{array}{l}\text { in the presence of harmful pathogens, the } \\
\text { interaction between the receptor-coated AgNP } \\
\text { and the bacterial surface is favored, causing } \\
\text { urease to catalytically raise the pH of the } \\
\text { solution, which allows detection by means of } \\
\text { a pH-sensitive chromogenic dye }\end{array}$ & 10 cells $\mathrm{mL}^{-1}$ & ND & 99 \\
\hline Piper betle $(\mathrm{Pb})$ & $\begin{array}{c}\text { Pseudomonas aeruginosa } \\
\text { Chromobacterium } \\
\text { violaceum }\end{array}$ & $\begin{array}{l}\text { molecular docking of eugenol-conjugated } \\
\text { AgNPs on quorum sensing regulatory } \\
\text { proteins is followed by FTIR analysis, } \\
\text { demonstrating that the phytochemical } \\
\text { components of Pb had blocked Pb-AgNPs; } \\
\text { this indicates that AgNP-eugenol system } \\
\text { exhibits considerable binding interactions } \\
\text { with QS-associated proteins }\end{array}$ & $12.5,25 \mu \mathrm{g} \mathrm{mL}^{-1}$ & 20 & 100 \\
\hline
\end{tabular}

NPs: nanoparticles; AgNP: silver nanoparticles; ND: not determined; FTIR: Fourier transform infrared spectroscopy; QS: quorum sensing. 

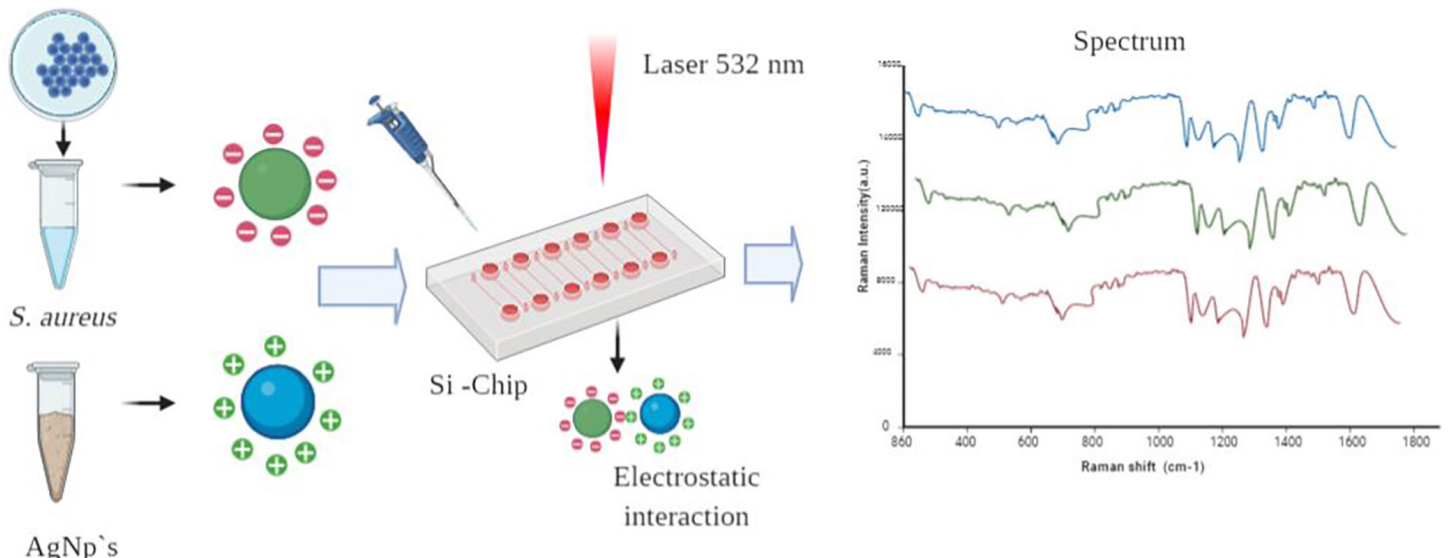

$$
\text { AgNp`s }
$$

Figure 4. In this AgNP biosensor, nanoparticles interact with the bacterial surface due to electrostatic forces when they are in contact with a silica-chip, generating changes in the SERS spectrum obtained using a Raman micro-spectrometer (adapted from Chen et al. ${ }^{74}$ ).

Table 7. Silica nanobiosensors used for pathogenic agent detection

\begin{tabular}{|c|c|c|c|c|c|}
\hline $\begin{array}{l}\text { Functionalized } \\
\text { substances }\end{array}$ & $\begin{array}{c}\text { Pathogens or analyte to } \\
\text { detect }\end{array}$ & Operating principle & Limit of detection & $\begin{array}{l}\text { Detection } \\
\text { time / min }\end{array}$ & Reference \\
\hline Antibody & Escherichia coli & $\begin{array}{l}\text { the bioconjugated nanoparticle can be followed } \\
\text { by an extremely high fluorescent signal, giving it } \\
\text { molecular biorecognition properties; } \\
\text { then, allowing fast and accurate identification of } \\
\text { a variety of bacteria }\end{array}$ & $1-400$ cells & 20 & 14 \\
\hline Dioxetane-polymyxin B & Escherichia coli & $\begin{array}{l}\text { the reaction of } \beta \text {-galactosidase enzyme from } \\
\text { E. coli with the dioxetane substrate generated } \\
\text { light at } 530 \mathrm{~nm} \text {; } \\
\text { the light emission for the porous silicon } \\
\text { biosensor chip with } E \text {. coli was significantly } \\
\text { more intense than that obtained for the control } \\
\text { system, pristine and flat silicon chip }\end{array}$ & $10^{1} \mathrm{CFU}$ & 30 & 102 \\
\hline D-Mannose & Escherichia coli & $\begin{array}{c}\text { an external magnetic field is applied to separate } \\
\text { the nanoparticles bound to the lectin from the } \\
\text { bacterial surface stained with a fluorescent dye } \\
\text { (Picogreen), a process recorded by fluorescence } \\
\text { microscopy }\end{array}$ & $10^{4}$ cells $\mathrm{mL}^{-1}$ & 5 & 43 \\
\hline $\begin{array}{l}\text { Carboxyl group and } \\
\text { monoclonal antibody }\end{array}$ & Vibrio cholerae & $\begin{array}{c}\text { SiNPs functionalized with carboxyl groups and } \\
\text { conjugated with monoclonal antibodies specific } \\
\text { for Vibrio cholerae are used as the amplification } \\
\text { signal to detect this bacteria using fluorescence } \\
\text { microscopy }\end{array}$ & 1 cell & 5 & 25 \\
\hline Antibody & Salmonella typhimurium & $\begin{array}{l}\text { the fluorescence intensity of } S \text {. typhimurium } \\
\text { incubated with the anti-S. typhimurium antibody } \\
\text { modified } \mathrm{Ru} \text { (bpy)-doped fluorescent NP was } \\
\text { measured by fluorescence microscopy; } \\
\text { the fluorescence response is proportional to the } \\
\text { quantity of } S \text {. typhimurium }\end{array}$ & $110 \mathrm{CFU} \mathrm{mL}^{-1}$ & 60 & 103 \\
\hline Antibody & $\begin{array}{c}\text { Salmonella and Escherichia } \\
\text { coli } \mathrm{O} 157\end{array}$ & $\begin{array}{l}\text { SiNPs doped with fluorescein isothiocyanate } \\
\text { and Ru(bpy), conjugated to the respective } \\
\text { antibodies and used in a conventional lateral } \\
\text { flow immunoassay, were followed using a } \\
\text { nitrocellulose strip analyzed by a smartphone- } \\
\text { based fluorimeter }\end{array}$ & $10^{5} \mathrm{CFU} \mathrm{mL}^{-1}$ & 10 & 104 \\
\hline Acridine orange & Staphylococcus aureus & $\begin{array}{l}\text { acridine Orange@ } \mathrm{SiO}_{2} \text { nanoparticles dispersed } \\
\text { with glutaraldehyde and incubated with } S . \text { aureus } \\
\text { were detected by fluorescence spectrophotometry }\end{array}$ & $500 \mathrm{CFU} \mathrm{mL}^{-1}$ & 20 & 105 \\
\hline $\begin{array}{l}\text { Positive (PAH) } \\
\text { and negative (PSS) } \\
\text { polyelectrolytes }\end{array}$ & Escherichia coli & $\begin{array}{l}\text { by cyclic voltammetry and QCM-D } \\
\text { measurements, the detection of Escherichia } \\
\text { coli is possible by tracking oxidation-reduction } \\
\text { reactions and frequency changes, respectively }\end{array}$ & ND & $2-4$ & 37 \\
\hline
\end{tabular}


Table 7. Silica nanobiosensors used for pathogenic agent detection (cont.)

\begin{tabular}{|c|c|c|c|c|c|}
\hline $\begin{array}{l}\text { Functionalized } \\
\text { substances }\end{array}$ & $\begin{array}{c}\text { Pathogens or analyte to } \\
\text { detect }\end{array}$ & Operating principle & Limit of detection & $\begin{array}{l}\text { Detection } \\
\text { time / min }\end{array}$ & Reference \\
\hline DNA & Salmonella typhimurium & $\begin{array}{l}\text { streptavidin conjugated to the surface } \\
\text { of COOH-FSiNPs (tris( } 2,2 \text { '-bipyridyl) } \\
\text { dichlororuthenium(II) hexahydrate doped with } \\
\text { carboxyl modified silica NPs) is incubated with } \\
\text { an aptamer labeled with specific ssDNA biotin; } \\
\text { this aptamer-bacteria system is treated with } \\
\text { synthetic streptavidin-conjugated silica } \\
\text { nanoprobes (SA-FSiNP) for the detection by } \\
\text { fluorescence of } S \text {. typhimurium }\end{array}$ & ND & 10 & 84 \\
\hline $\begin{array}{l}\text { Polyelectrolyte } \\
\text { multilayer (PEM) }\end{array}$ & Escherichia coli & $\begin{array}{l}\text { functionalization applied to an electrochemical } \\
\text { transducer for the detection of Escherichia coli }\end{array}$ & $10^{6}-10^{3} \mathrm{CFU} \mathrm{mL}^{-1}$ & $5-30$ & 51 \\
\hline Polyclonal antibody & Brucella abortus & $\begin{array}{l}\text { the addition of conjugates to the bacterial } \\
\text { suspension forms PMNP sandwich structures } \\
\text { of Brucella abortus-blue-SiNPs (possible to } \\
\text { separate by a magnet), releasing a blue tint } \\
\text { measurable by absorbance at } 670 \mathrm{~nm}\end{array}$ & $450 \mathrm{CFU} \mathrm{mL}^{-1}$ & 60 & 106 \\
\hline $\begin{array}{l}\text { Hemin } \\
\text { (chemiluminescent (CL) } \\
\text { tag molecule) }\end{array}$ & $\begin{array}{l}\text { Escherichia coli } \mathrm{O} 157: \mathrm{H} 7 \\
\text { Staphylococcus aureus }\end{array}$ & $\begin{array}{l}\text { CL was encapsulated in silica NPs with ordered } \\
\text { mesopores; DNA can specifically change upon } \\
\text { exposure to DNA nuclease or bacterial lysate } \\
\text { through the use of a specific DNA gate, resulting } \\
\text { in a more significant release of encapsulated } \\
\text { hemin and resulting in an improved CL signal for } \\
\text { the luminol- } \mathrm{H}_{2} \mathrm{O}_{2} \text { system } \\
\end{array}$ & $\begin{array}{c}3.0 \\
2.5 \mathrm{CFU} \mathrm{\textrm {mL } ^ { - 1 }}\end{array}$ & 60 & 107 \\
\hline $\begin{array}{l}\text { Organic dyes (dark blue, } \\
\text { reaction green, reaction } \\
\text { blue, bright red, and } \\
\text { reactive purple) }\end{array}$ & Pseudomonas aeruginosa & $\begin{array}{c}\text { monodisperse-colored SiNPs as agglutination } \\
\text { test vehicles were prepared using reverse } \\
\text { microemulsion; } \\
\text { the SiNPs were sensitized with eleven } \\
\text { types of monospecific antibodies against } \\
\text { Pseudomonas aeruginosa (IgG-colored SiNPs); } \\
\text { the agglutination test was able to identify } \\
\text { different serotypes of } P \text {. aeruginosa }\end{array}$ & $10^{9} \mathrm{CFU} \mathrm{mL}^{-1}$ & $1-3$ & 108 \\
\hline
\end{tabular}

CFU: colony-forming unit; SiNPs: silica nanoparticles; Ru(bpy): tris(bipyridine)ruthenium(II) chloride; NPs: nanoparticles; QCM-D: quartz crystal microbalance; ND: not determined; DNA: deoxyribonucleic acid; ssDNA: single-stranded DNA; PMNP: paramagnetic nanoparticles; IgG: immunoglobuline G.

pathogenic agent Escherichia coli $\mathrm{O} 157: \mathrm{H} 7$ in beef samples with the help of a spectrofluorometer.

Chitra and Annadurai ${ }^{26}$ used a similar immunoassay for detecting Escherichia coli using antibodies conjugated with SiNP functionalized with carboxyl groups and fluorescent dyes, the latter based on the reactive amino dyes dimethylformamide and 3-amino propyltriethoxysilane

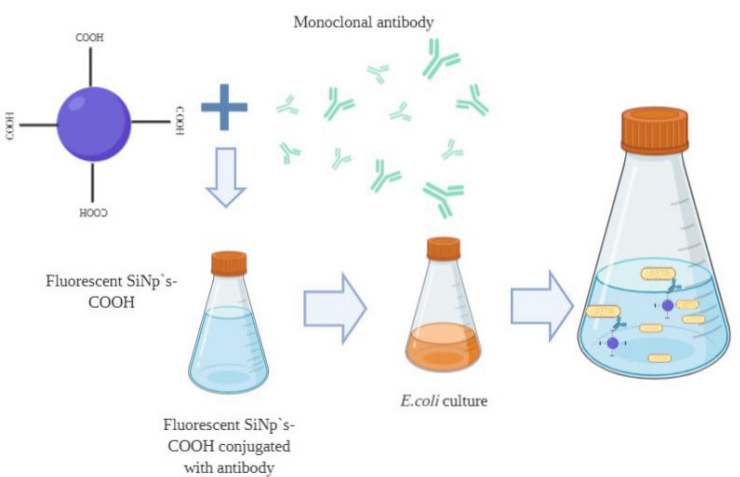

(Figure 5). The results showed nanoparticle emission at $536 \mathrm{~nm}$ and the presence of nanoparticle-bacteria aggregates, suggesting that several antibodies could bind to the cell surface. This method provides a fast, accurate, and straightforward way for the detection of pathogens using fluorescence-based immunoassays.

Figure 5. Nanobiosensor using fluorescent SiNPs functionalized with a monoclonal antibody. In the presence of the bacteria, the antibody-antigen interaction occurs, and changes are observed in the excitation and emission spectrum of the functionalized SiNPs (adapted from Chitra and Annadurai ${ }^{26}$ ). 


\subsection{Biosensors with magnetic nanoparticles}

Magnetic nanoparticles (MNPs) are biocompatible structures with adjustable sizes, making them ideal for a wide range of biomedical or biotechnological applications, especially for magnetic resonance imaging, magnetic labeling of secreted bioactive molecules, nanosorbents in environmental decontamination technologies, and biosensors (Table 8). ${ }^{109}$ Among the most innovative methods for detecting pathogens are those based on magnetic nanoparticles coupled to biorecognition elements such as antibodies, proteins, viruses, bacteria, or nucleic acids. This type of nanoparticles has been used to detect immobilized targets by applying a magnetic field to the magnetic nanoparticles or using conductometry, due to its excellent conductive properties, as part of the biosensor. ${ }^{2,10}$
As an example, a methodology that allows the identification and quantification of DNA and messenger ribonucleic acid (mRNA) employs iron oxide with various ligands such as peptides, antibodies, and nucleic acids on the nanoparticle surface. ${ }^{2}$ Also, nanoparticles that use magnetism can allow the isolation of the analyte of interest. This methodology is known as immunocapture of pathogenic bacteria, a variant of the conventional enzyme-linked immunoassay (ELISA) technique, with capture efficiencies of up to $97 \%$.

Joo et al. ${ }^{77}$ reported a straightforward and sensitive analytical method for detecting bacteria such as Salmonella in milk. After forming an interaction between the bacteria and antibody-conjugated magnetic nanoparticle, the bacteria were separated from the sample by an external magnetic field. Subsequently, the MNP-Salmonella complexes were dispersed in a buffer solution and exposed

Table 8. Magnetic nanobiosensors used for pathogenic agent detection

\begin{tabular}{|c|c|c|c|c|c|}
\hline $\begin{array}{l}\text { Functionalized } \\
\text { substances }\end{array}$ & $\begin{array}{c}\text { Pathogens or analyte to } \\
\text { detect }\end{array}$ & Operating principle & Limit of detection & $\begin{array}{l}\text { Detection } \\
\text { time / min }\end{array}$ & Reference \\
\hline $\begin{array}{l}\text { Nanoparticle-based } \\
\text { proteomic } \\
\text { strategies }\end{array}$ & $\begin{array}{l}\text { Escherichia } \\
\text { coli } \mathrm{O} 157: \mathrm{H} 7\end{array}$ & $\begin{array}{l}\text { a method based on tryptic digestion of bacteria } \\
\text { captured under magnetic NP microwave irradiation } \\
\text { of } \mathrm{Fe}_{3} \mathrm{O}_{4} \text {, followed by matrix-assisted laser } \\
\text { ionization/desorption mass spectrometry analysis }\end{array}$ & 30 cells $\mathrm{mL}^{-1}$ & 1.5 & 90 \\
\hline Peptide & $\begin{array}{l}\text { Escherichia } \\
\text { coli } \mathrm{O} 157: \mathrm{H} 7\end{array}$ & $\begin{array}{l}\text { biosensor based on the ability of } E \text {. coli } \mathrm{O} 157: \mathrm{H} 7 \\
\text { proteases to modify their optical response; } \\
\text { the gradual increase in the sensor surface's golden } \\
\text { hue after proteolysis can be correlated with the } \\
\text { concentration of } E \text {. coli } \mathrm{O} 157: \mathrm{H} 7 \text { in the sample }\end{array}$ & $12 \mathrm{CFU} \mathrm{mL}^{-1}$ & ND & 110 \\
\hline $\begin{array}{l}\text { Amine-functionalized } \\
\text { magnetic nanoparticles } \\
\text { (AFMNPs) }\end{array}$ & Escherichia coli & $\begin{array}{l}\text { the positive charges on the surface of unmodified } \\
\text { AFMNP promote strong electrostatic interactions } \\
\text { with negatively charged sites on the surface of } \\
\text { bacterial pathogens }\end{array}$ & ND & 10 & 56 \\
\hline Antibody & Escherichia coli & $\begin{array}{l}\text { the immobilization of biotin-labeled anti- } \\
\text { Escherichia coli antibodies on avidin-coated } \\
\text { magnetic nanoparticles allowed the synthesis of } \\
\text { gold-coated magnetic NPs, a biosensor capable of } \\
\text { separating and quantifying Escherichia coli }\end{array}$ & $8 \mathrm{CFU} \mathrm{mL} \mathrm{m}^{-1}$ & 70 & 59 \\
\hline Gentamicin $(\mathrm{Gm})$ & Staphyloccocus aureus & $\begin{array}{l}\text { the combination of a magnetic nucleus }\left(\mathrm{Fe}_{3} \mathrm{O}_{4}\right) \text {, a } \\
\text { fluorescent layer }\left(\mathrm{SiO}_{2}\right) \text {, and the conjugation with } \\
\mathrm{Gm} \text {, known as } \mathrm{Gm}-\mathrm{MNP} \text {, allows the capture of } \\
\text { S. aureus cells through magnetic interaction with } \\
\text { the Gm-MNP system }\end{array}$ & $500 \mathrm{CFU} \mathrm{mL}-1$ & 1 & 65 \\
\hline $\begin{array}{l}\text { Immunofluorescent } \\
\text { nanospheres (IFNS) }\end{array}$ & Salmonella typhimurium & $\begin{array}{l}\text { the combination of immunomagnetic nanospheres } \\
\text { and IFNS allows the capture and specific } \\
\text { recognition of } S \text {. typhimurium; } \\
\text { the sandwich-type immune complex } \\
\text { (IMNS-bacteria-IFNS) formed is easily analyzed } \\
\text { by a fluorescence microscope }\end{array}$ & $10 \mathrm{CFU} \mathrm{mL}^{-1}$ & ND & 39 \\
\hline $\begin{array}{l}\text { Biotin-probe labeled } \\
\text { magnetic beads (MBs) }\end{array}$ & Salmonella sp. & $\begin{array}{l}\text { the primers were designed to produce } \\
\text { MBs-ssDNA; using } \mathrm{Fe}_{3} \mathrm{O}_{4} \mathrm{NPs} \text {, the target ssDNA } \\
\text { is isolated, which hybridized with the reporter } \\
\text { probes can decrease signal }\end{array}$ & $74 \mathrm{CFU} \mathrm{mL}^{-1}$ & 80 & 54 \\
\hline Streptavidin & Salmonella sp. & $\begin{array}{c}\mathrm{Fe}_{3} \mathrm{O}_{4} \text { modified with streptavidin was used to } \\
\text { capture biotinylated antibody and determine } \\
\text { streptavidin interaction, reducing the transverse } \\
\text { relaxation time of neighboring water molecules } \\
\text { analyzed by NMR }\end{array}$ & $10^{5} \mathrm{CFU} \mathrm{mL}^{-1}$ & 60 & 111 \\
\hline
\end{tabular}


Table 8. Magnetic nanobiosensors used for pathogenic agent detection (cont.)

\begin{tabular}{|c|c|c|c|c|c|}
\hline $\begin{array}{l}\text { Functionalized } \\
\text { substances }\end{array}$ & $\begin{array}{c}\text { Pathogens or analyte to } \\
\text { detect }\end{array}$ & Operating principle & Limit of detection & $\begin{array}{l}\text { Detection } \\
\text { time / min }\end{array}$ & Reference \\
\hline Peptide & Stachybotrys chartarum & $\begin{array}{l}\text { peptide-labeled MNP fragments can be formed } \\
\text { from Stachybotrys chartarum culture supernatant } \\
\text { dripped onto a nano-wave; } \\
\text { fragments can be split off and attracted by an } \\
\text { external magnet, causing a golden coloration } \\
\text { visible to the naked eye and indicating a positive } \\
\text { reading }\end{array}$ & $10-100$ spores $\mathrm{mL}^{-1}$ & 1 & 53 \\
\hline $\begin{array}{l}\text { Antibodies (Abs) } \\
\text { CSA-1-Ab }\end{array}$ & S. typhimurium & $\begin{array}{l}\text { through the development of a nano platform, } \\
\text { FPMNPs is possible to detect and capture } \\
\text { S. typhimurium; } \\
\text { the covalent binding of Abs facilitates the capture } \\
\text { and immunomagnetic separation of the pathogen } \\
\text { from a food matrix, allowing the obtaining of a } \\
\text { SERS signal utilizing Raman }\end{array}$ & 100 cells $\mathrm{mL}^{-1}$ & 60 & 41 \\
\hline$N$-Succinyl feroxamine & Yersinia enterocolitica & $\begin{array}{l}\text { by binding bacteria to the MNP conjugate due to } \\
\text { the MNP surface's electrostatic interactions and } \\
\text { the feroxamine receptor, detection is possible }\end{array}$ & ND & 60 & 112 \\
\hline
\end{tabular}

NPs: nanoparticles; CFU: colony-forming unit; ND: not determined; IMNS: immunomagnetic nanosphere; MBs-ssDNA: biotin-probe labeled magnetic beads-single-stranded DNA; FPMNPs: functionalized polymeric magnetic nanoparticles; NMR: nuclear magnetic resonance; MNP: magnetic nanoparticles; SERS: surface-enhanced Raman spectroscopy; GNPs: gold nanoparticles; MB: magnetic beads.

to antibody-immobilized $\mathrm{TiO}_{2}$ nanocrystals $(\mathrm{TN})$. This new MNP-Salmonella-TN complex is separated from the sample, and the UV-Vis spectra of the unbound TN solution and the MNP-Salmonella-TN complex are compared to allow the detection of low concentrations of Salmonella, reaching limits of detection in milk as low as 100 colonyforming unit (CFU) $\mathrm{mL}^{-1}$ (Figure 6).

Finally, it should be noted that one of the major disadvantages of MNPs is their water stability, which has been the subject of recent efforts, especially through

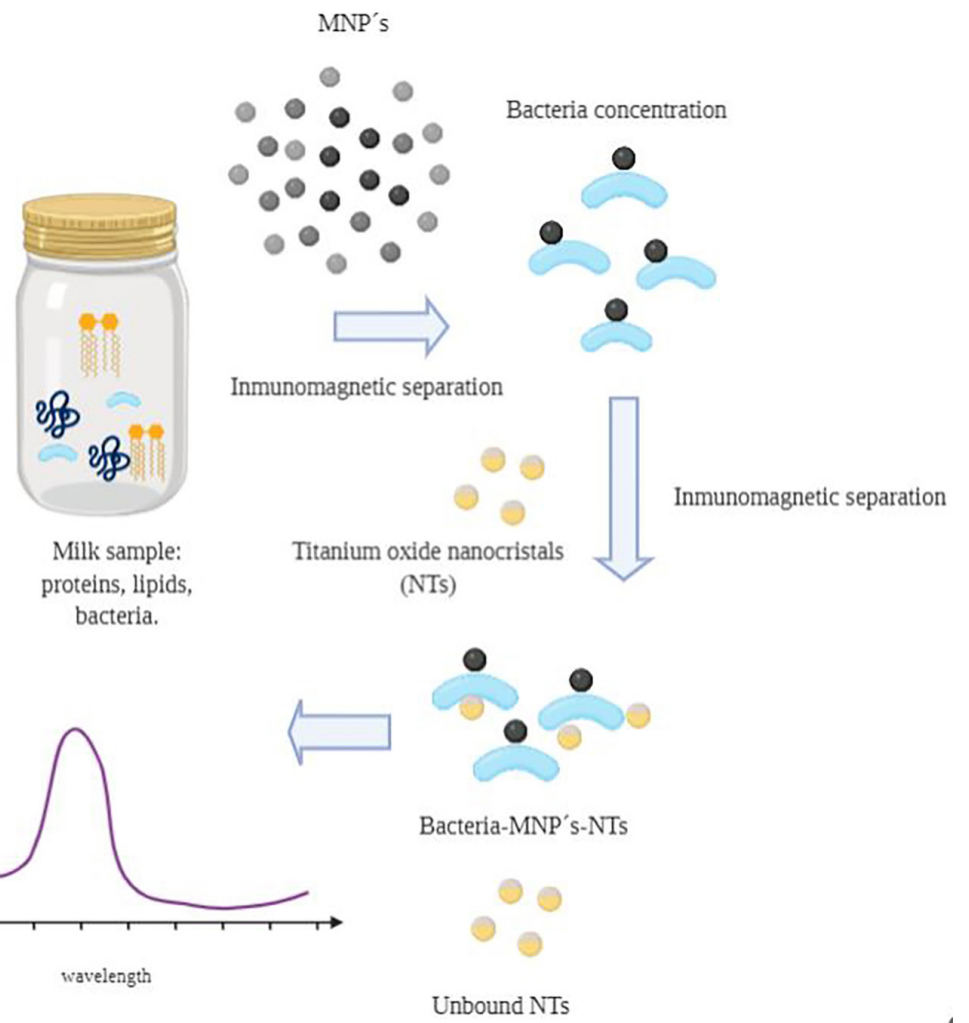

Figure 6. Nanobiosensor using magnetic nanoparticles (MNPs) and titanium oxide nanocrystals (NTs) attached to antibodies to detect Salmonella sp. in milk. First, an immunomagnetic separation is carried out to obtain the MNPs bound to the bacteria. Titanium oxide nanocrystals (NTs) are then added, and a second immunoseparation is carried out to obtain MNPs-NTs-Salmonella complexes and free NTs with differentiated spectra (adapted from Joo et al. ${ }^{77}$ ). 
functionalization strategies, such as the binding to dextran and polyacrylic acid..$^{90}$

\subsection{Biosensors with quantum dots (QDs)}

QDs are inorganic fluorophores that have replaced, to some extent, conventional fluorescent dyes, exhibiting unique light emission properties according to their size and composition. Another characteristic of QDs is their narrow emission spectrum that differs according to the size and type of material, allowing the emission of sharp colors with high resolution and improving assays' sensitivity. ${ }^{11,29,40}$

One of the most critical advantages of QDs, in addition to the fact that they show minimal interference with natural autofluorescent particles ${ }^{75,113}$ is their ability to simultaneously detect several biomarkers, due to the phenomenon known as synchronous emission, which allows different QDs to show excitation at the same wavelength. ${ }^{10,75}$ They also have disadvantages, such as unstable fluorescence generation, cytotoxicity, ${ }^{101}$ and their "lipid-like" surface, which restricts the compatibility of QDs in aqueous environments and biological fluids. It is both the advantages and disadvantages that allow QDs to be used in cell and virus marking, immunofluorescence assays, and flow cytometry. The latter application has great potential since they replace traditionally used fluorescent organic dyes (Table 9), ${ }^{11}$ making screening tests more efficient by reducing analysis time.

Additionally, QDs have been reported to detect biomarkers such as antigens and pathogens, ${ }^{12}$ to act as probes to detect genomic DNA, and to be employed for fluorescent

Table 9. Quantum dots nanobiosensors used for pathogenic agent detection

\begin{tabular}{|c|c|c|c|c|c|}
\hline $\begin{array}{l}\text { Functionalized } \\
\text { substances }\end{array}$ & $\begin{array}{l}\text { Pathogens or analyte to } \\
\text { detect }\end{array}$ & Operating principle & Limit of detection & $\begin{array}{l}\text { Detection } \\
\text { time } / \mathrm{h}\end{array}$ & Reference \\
\hline Thiol-ssDNA & Escherichia coli & $\begin{array}{l}\text { a thiol-ssDNA-QD sensor was developed through } \\
\text { a metal-thiol bond between the QD and the DNA } \\
\text { system; } \\
\text { bacteria in situ hybridization experiments were } \\
\text { carried out, incubating cells with DNA; } \\
\text { the cells were detected with an inverted } \\
\text { fluorescence microscope }\end{array}$ & ND & 1 & 114 \\
\hline $\begin{array}{l}\text { Biotinylated } \\
\text { bacteriophage }\end{array}$ & Escherichia coli & $\begin{array}{l}\text { a specific bacteriophage for Escherichia coli was } \\
\text { biotinylated in vivo, using a short peptide on the } \\
\text { capsid surface marked with QDs coated with } \\
\text { estraptivirin; } \\
\text { phage infection allowed the visualization of the } \\
\text { bacteria in water samples regardless of the presence } \\
\text { of several mixtures of bacterial species }\end{array}$ & 10 cells $\mathrm{mL}^{-1}$ & 1 & 57 \\
\hline Antibody & $\begin{array}{l}\text { Salmonella typhimurium, } \\
\text { Escherichia coli } \mathrm{O} 157: \mathrm{H} 7 \\
\text { and Listeria monocytogenes }\end{array}$ & $\begin{array}{l}\text { the immuno-MNBs mixture allows to capture and } \\
\text { magnetically separate three target bacteria in food } \\
\text { samples; } \\
\text { fluorescence intensity of MNB-cell-QD complexes } \\
\text { determines the populations of pathogens }\end{array}$ & $50 \mathrm{CFU} \mathrm{mL}^{-1}$ & 2 & 115 \\
\hline Antibody IgG & Salmonella typhimurium & $\begin{array}{l}\text { CdSe/ZnS QDs were immobilized onto a porous } \\
\text { polycarbonate membrane having bound IgG } \\
\text { antibodies specific for Salmonella tiphymurium; } \\
\text { these nanostructures were used as fluorochromes } \\
\text { during immunodetection; } \\
\text { the capture of the cells was detected by confocal } \\
\text { laser microscopy }\end{array}$ & 100 cells $\mathrm{mL}^{-1}$ & 2 & 116 \\
\hline $\begin{array}{l}\text { Amino-modified } \\
\text { aptamers }\end{array}$ & Salmonella typhimurium & $\begin{array}{l}\text { the fluorescence detection of } \\
\text { Salmonella typhimurium followed the incubation } \\
\text { time and the addition of CD-aptamers; } \\
\text { a linear relationship between the concentration } \\
\text { of Salmonella typhimurium and the intensity of } \\
\text { fluorescence was achieved }\end{array}$ & $50 \mathrm{CFU} \mathrm{mL}^{-1}$ & ND & 117 \\
\hline Antibody & Staphylococcus aureus & $\begin{array}{c}\text { QDs coated with streptavidin and conjugated } \\
\text { with biotin-labeled anti-S. aureus antibodies were } \\
\text { developed as fluorescence markers; } \\
\text { the fluorescence intensity of the bead-cell-QD } \\
\text { complexes in the presence of } S \text {. aureus at } 620 \mathrm{~nm} \\
\text { allows detection }\end{array}$ & $10^{3} \mathrm{CFU} \mathrm{mL}^{-1}$ & 2 & 79 \\
\hline
\end{tabular}


Table 9. Quantum dots nanobiosensors used for pathogenic agent detection (cont.)

\begin{tabular}{|c|c|c|c|c|c|}
\hline $\begin{array}{l}\text { Functionalized } \\
\text { substances }\end{array}$ & $\begin{array}{c}\text { Pathogens or analyte to } \\
\text { detect }\end{array}$ & Operating principle & Limit of detection & $\begin{array}{l}\text { Detection } \\
\text { time / h }\end{array}$ & Reference \\
\hline Antibody & Salmonella enteritidis & $\begin{array}{l}\text { the specific interaction between } \\
\text { Salmonella enteritidis and CdTe QDs modified with } \\
\text { ligands conjugated to anti-Salmonella antibodies } \\
\text { allows the capture and detection of } \\
\text { Salmonella enteritidis by fluorescence microscopy }\end{array}$ & $10^{2} \mathrm{CFU} \mathrm{mL} \mathrm{m}^{-1}$ & 2 & 71 \\
\hline $\begin{array}{l}\text { Metal-organic } \\
\text { frameworks }\end{array}$ & $\begin{array}{c}\text { Escherichia coli } \\
\text { O157:H7 }\end{array}$ & $\begin{array}{l}\text { CdS@ZIF-8 NPs as signal tags allow detection of } \\
\text { Escherichia coli O157:H7; } \\
\text { detection is made possible by differential pulse } \\
\text { voltammetry when analyzing cadmium(II) ions } \\
\text { released from CdS@ZIF-8 tags by HCl leaching }\end{array}$ & $3 \mathrm{CFU} \mathrm{mL} \mathrm{m}^{-1}$ & 1 & 81 \\
\hline $\begin{array}{l}\text { Metronidazole } \\
\text { (MET) }\end{array}$ & Porphyromonas gingivalis & $\begin{array}{l}\text { the ability of oral epithelial cells (H413) with } \\
\text { cCQDs to attack intracellular pathogens was } \\
\text { studied; } \\
\text { cell nuclei stained with DAPI produced a strong } \\
\text { emission; } \\
\text { it was found a cCQDs penetration capacity of } 80 \% \\
\text { (m/m) using UV-Vis spectroscopy }\end{array}$ & $0.26 \mu \mathrm{mol} \mathrm{L}^{-1}$ & 180 & 50 \\
\hline $\begin{array}{l}\mathrm{ZnO} \text { nanowire array } \\
(\mathrm{NWs})\end{array}$ & $\begin{array}{c}\text { Escherichia coli } \\
\text { O157:H7 }\end{array}$ & $\begin{array}{l}\text { an aptamer as a recognition element made up of } \\
\text { aligned ZnO NWs, decorated with AuNP and CdS } \\
\text { QDs, allowed to form a nanoarray that can act as a } \\
\text { self-amplified PEC biosensor }\end{array}$ & $1.125 \mathrm{CFU} \mathrm{mL}^{-1}$ & 60 & 42 \\
\hline Antibody & Salmonella sp. & $\begin{array}{l}\text { considering that metal ion signals can be correlated } \\
\text { with the number of bacterial cells captured by } \\
\text { the sensor, QDs (CdTe) were studied by } \\
\text { voltammetry after their acid dissolution using } \\
\text { carbon electrodes screen-printed with bismuth(III) } \\
\text { film formed in situ }\end{array}$ & $4 \mathrm{CFU} \mathrm{mL}^{-1}$ & 150 & 55 \\
\hline $\begin{array}{l}\text { Manganese dioxide } \\
\text { nanoflowers } \\
\left(\mathrm{MnO}_{2} \mathrm{NFs}\right)\end{array}$ & $\begin{array}{c}\text { Escherichia coli } \\
\text { O157:H7 Salmonella }\end{array}$ & $\begin{array}{c}\text { target bacteria were conjugated to } \\
\text { pAb-QDs@ } \mathrm{MnO}_{2} \text { nanocomposites, where } \\
\text { antibodies (pAbs) help form MNB-bacteria- } \\
\text { QM complexes, whose fluorescent intensity at } \\
\text { the characteristic wavelength was measured to } \\
\text { determine the presence of the target bacteria after } \\
\text { separating QD and } \mathrm{Mn}^{2+} \text { ions }\end{array}$ & $15,40 \mathrm{CFU} \mathrm{mL} \mathrm{m}^{-1}$ & 120 & 80 \\
\hline
\end{tabular}

in situ hybridization assays (FISH). ${ }^{10}$ Recognition of pathogens with this type of nanosensors is based on the functionalization of the nanoparticles with specific antibodies, which upon contact with the pathogen, and due to the affinity given by the functionalization, create an antigen-antibody species that emits a fluorescence signal. ${ }^{34,58}$ Zhu et al. ${ }^{89}$ studied two different bioconjugates QDs as biosensors, using biotinylated antibodies generating a dualcolor image for two protozoa: Cryptosporidium parvum and Giardia lamblia. Tully et al. ${ }^{29}$ developed a rapid immunoassay based on QDs fluorescence for the detection of two surface proteins of Listeria monocytogenes, poly(amino acids) involved in the invasion of human cells, called internalin A and internalin B. Another strategy reported to recognize pathogens, specifically Escherichia coli, uses QDs coated with mannose, nanostructures that identify the mannose-specific lectin FimH from the surface of Escherichia coli, allowing the detection of bacteria in cell suspensions with less than $10^{4}$ cells $\mathrm{mL}^{-1} .^{58}$ There is also the work with magnetic QDs conjugated with anti-Salmonella antibodies by Yang et al. ${ }^{113}$ where the intensity of the fluorescence emitted by the QDs is used for the detection of the pathogen (Figure 7).

\subsection{Biosensors with carbon nanotubes}

Several zero-dimensional (0D) to three-dimensional (3D) carbon nanomaterials have been developed as electrochemical biosensors, showing that the analysis of bacterial pathogens in food through carbon nanotubes (CNTs), graphene, and their derivatives, improves the detection sensitivity, mainly when electrochemistry is used as an analysis method. For example, carbon nanotubes with a large surface-to-volume ratio make it possible to acquire and distinguish electrical signals before and after biological elements hybridization. ${ }^{68}$ 

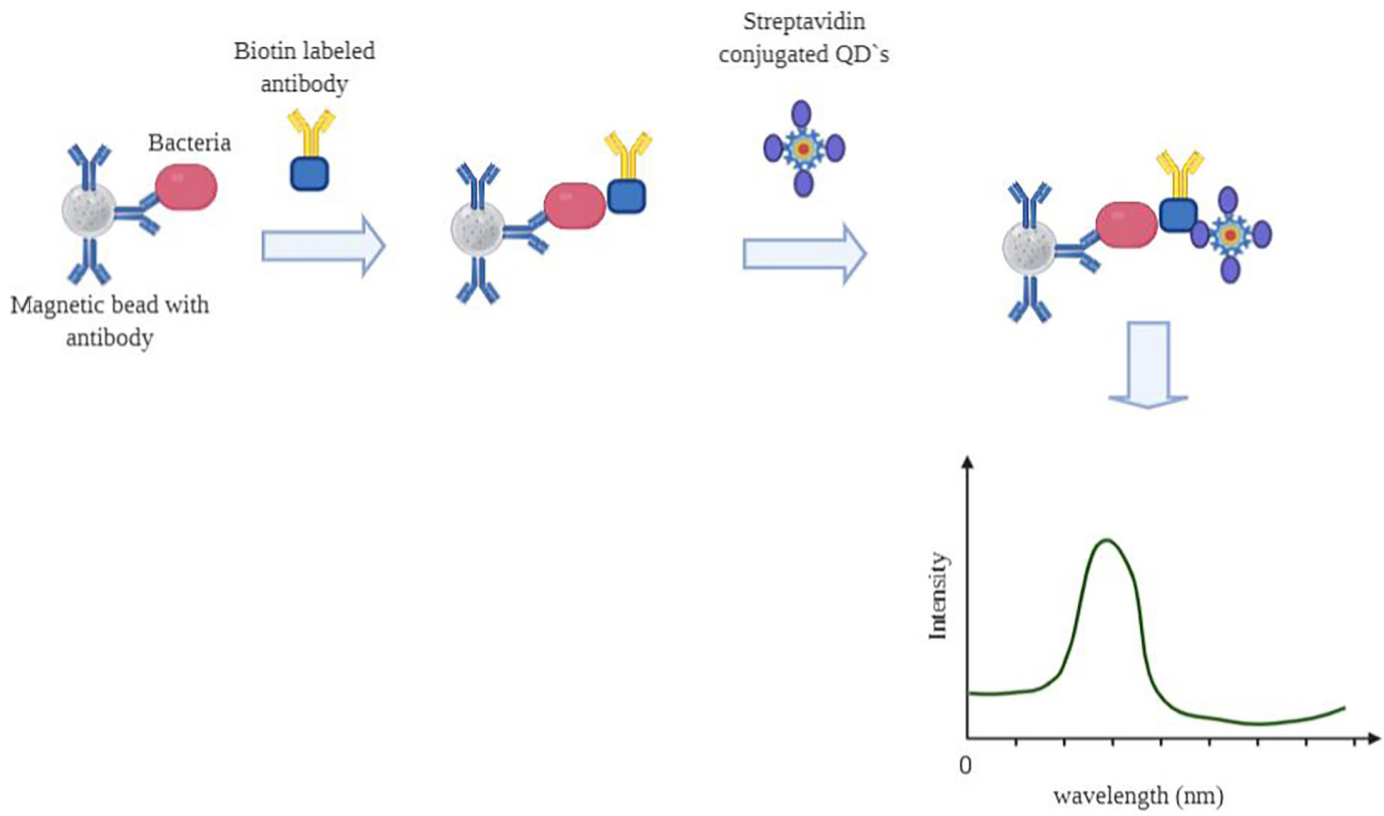

Figure 7. Magnetic beads attached to antibodies are used to detect bacteria in a sample. A secondary biotin-conjugated antibody reacts with the detected bacteria. QDs conjugated with streptavidin are used as fluorescent probes given the biological interaction streptavidin-biotin. The bacterial density can be measured given the intensity of the fluorescence emitted by the QDs (adapted from Yang et al. ${ }^{113}$ ).

Carbon nanotubes are graphene tubules made up of monoatomic layers of hexagonal bonded carbon atoms wound on their axis. They are found as simple nanotubes (rolled graphene sheets) or multiple nanotubes (several nested concentric sheets) that absorb infrared light, giving them properties such as biorecognition-signal amplifiers and transducers. ${ }^{33}$ Due to their attractive electronic, optical, and thermal properties, they can be used in nanomedicine (Table 10).
It is known that CNTs can be bio-persistent, maintaining their physicochemical characteristics unaltered in the environment without degrading and having the capacity to generate adverse effects in the exposed organisms. For that reason, strategies have been developed that improve their biocompatibility through surface modification with proteins, antibodies, and nucleic acids. On the other hand, it has recently been reported that these structures may be susceptible to biodegradation,

Table 10. Carbon nanotubes used for pathogenic agent detection

\begin{tabular}{|c|c|c|c|c|c|}
\hline $\begin{array}{l}\text { Functionalized } \\
\text { substances }\end{array}$ & Pathogens & Operating principle & Limit of detection & $\begin{array}{c}\text { Detection } \\
\text { time / h }\end{array}$ & Reference \\
\hline $\begin{array}{l}\text { Bovine serum albumin } \\
\text { (BSA) }\end{array}$ & $\begin{array}{c}\text { Escherichia coli } \\
\text { O157:H7 }\end{array}$ & $\begin{array}{l}\text { immuno-SWNT, made up of goat anti- } \\
\text { Escherichia coli } \text { O157 antibody conjugated to } \\
\text { SWNT-BSA, makes it possible to recognize } \\
\text { pathogenic Escherichia coli O157:H7 cells } \\
\text { through specific antibody-antigen interactions }\end{array}$ & ND & 1 & 118 \\
\hline Galactose (Gal) & $\begin{array}{c}\text { Escherichia coli } \\
\text { O157:H7 }\end{array}$ & $\begin{array}{l}\text { SWNT, as a vehicle for multiple carbohydrate } \\
\text { ligands, allows capturing pathogenic } \\
\text { Escherichia coli in physiological solutions; } \\
\text { furthermore, water-soluble SWNTs conjugated } \\
\text { with galactose may exhibit inhibition of } \\
\text { specific cellular responses }\end{array}$ & ND & 1 & 119 \\
\hline Antibody (Ab) & Salmonella infantis & $\begin{array}{l}\text { using the transduction capacity of CNTFETs } \\
\text { combined with the antigen-antibody interaction } \\
\text { recognition capacity produces a fast, sensitive, } \\
\text { and tag-free biosensor for the selective } \\
\text { detection of } S \text {. infantis }\end{array}$ & $100 \mathrm{CFU} \mathrm{mL}^{-1}$ & 1 & 46 \\
\hline Antibody (Ab) & Candida albicans & $\begin{array}{c}\text { monoclonal anti-Candida antibodies adsorbed } \\
\text { on SWCNT provide specific binding sites for } \\
\text { fungal antigens; } \\
\text { the methodology uses a FET in which } \\
\text { SWCNTs form the conducting channel }\end{array}$ & $50 \mathrm{CFU} \mathrm{mL}^{-1}$ & 1 & 63 \\
\hline
\end{tabular}


Table 10. Carbon nanotubes used for pathogenic agent detection (cont.)

\begin{tabular}{|c|c|c|c|c|c|}
\hline $\begin{array}{l}\text { Functionalized } \\
\text { substances }\end{array}$ & Pathogens & Operating principle & Limit of detection & $\begin{array}{c}\text { Detection } \\
\text { time } / \mathrm{h}\end{array}$ & Reference \\
\hline Antibody (Ab) & $\begin{array}{c}\text { Escherichia coli } \\
\text { O157:H7 Bacteriophage } \\
\text { T7 }\end{array}$ & $\begin{array}{l}\text { specific Ab-functionalized SWNTs-bonded } \\
\text { gold electrodes act as chemoresistive } \\
\text { biosensors; } \\
\text { the functionalization with specific Ab of } \\
\text { various microorganisms was carried out } \\
\text { covalently }\end{array}$ & $10^{5}, 10^{3} \mathrm{CFU} \mathrm{mL} \mathrm{m}^{-1}$ & 0.1 & 64 \\
\hline Antibody (Ab) & $\begin{array}{l}\text { Salmonella enterica } \\
\text { serovar Typhimurium }\end{array}$ & $\begin{array}{l}\text { a bioconjugate of Ab/SWCNTs/HRP was } \\
\text { used in ELISA experiments for high protein } \\
\text { recovery; } \\
\text { in this, the SWCNTs serve for the co- } \\
\text { immobilization of antibodies and horseradish } \\
\text { peroxidase }\end{array}$ & $10^{3}-10^{4} \mathrm{CFU} \mathrm{mL}^{-1}$ & 2 & 76 \\
\hline Antibody (Ab) & rotavirus & $\begin{array}{l}\text { a graphene film with a uniform ripple structure } \\
\text { on the surface shows high conductivity and } \\
\text { rapid electron transfer properties, allowing it to } \\
\text { work as an electrode in cyclic voltammetry }\end{array}$ & $10^{5} \mathrm{PFU} \mathrm{mL} \mathrm{L}^{-1}$ & ND & 87 \\
\hline DNA & $\begin{array}{c}\text { Escherichia coli } \\
\text { O157:H7 }\end{array}$ & $\begin{array}{l}\text { the interaction between a DNA sequence and } \\
\text { the MWCNTs during the preparation of a } \\
\text { DNA sensor was investigated using Raman } \\
\text { spectroscopy and Fourier transform infrared } \\
\text { spectroscopy }\end{array}$ & $1 \mathrm{nM}$ & 2 & 66 \\
\hline $\begin{array}{l}\text { Pyrenil and amine- } \\
\text { modified aptamers }\end{array}$ & Staphylococcus aureus & $\begin{array}{l}\text { a network of SWCNTs acting as an ion- } \\
\text { to-electron potentiometric transducer and } \\
\text { anti-S. aureus aptamers, as the recognition } \\
\text { element, showed a linear behavior between the } \\
\text { potential and the bacteria concentration }\end{array}$ & $800 \mathrm{CFU} \mathrm{mL}^{-1}$ & 48 & 78 \\
\hline $\begin{array}{l}\text { DNAzyme-labeled } \\
\text { aptamer }\end{array}$ & Salmonella paratyphi A & $\begin{array}{l}\text { aptamers with high binding capacity and } \\
\text { specificity against Salmonella paratyphi A } \\
\text { were developed; } \\
\text { the aptamer-pathogen interaction was followed } \\
\text { by fluorescence }\end{array}$ & $10^{3} \mathrm{CFU} \mathrm{mL}^{-1}$ & 15 & 120 \\
\hline Metal nanoparticle & $\begin{array}{c}\text { Escherichia coli } \\
\text { O157:H7 }\end{array}$ & $\begin{array}{l}\text { AuNPs-3D graphene interdigitated array } \\
\text { electrodes were converted from polyimide film } \\
\text { coated with the corresponding metal precursor- } \\
\text { chitosan hydrogel ink and used to fabricate a } \\
\text { flexible impedimetric immunosensor }\end{array}$ & $100 \mathrm{CFU} \mathrm{mL} \mathrm{m}^{-1}$ & 0.5 & 70 \\
\hline Antibody & Yersinia enterocolitica & $\begin{array}{l}\text { a biosensor based on SWCNT immobilized } \\
\text { with anti-Yersinia antibody showed that, by } \\
\text { linear scanning voltammetry, it is possible to } \\
\text { detect the pathogen }\end{array}$ & $10^{4} \mathrm{CFU} \mathrm{mL}^{-1}$ & 0.5 & 73 \\
\hline
\end{tabular}

which increases the possibility of application in living systems. ${ }^{10,33}$

DNA probes have been shown to degrade when exposed to cellular enzymes or nucleases present in samples during the development of molecular techniques. However, the use of CNTs protects these biomolecules since the interaction between single-stranded DNA nucleotides and simple nanotubes allows the formation of a stable complex, making its degradation more difficult. ${ }^{10}$ This concept was proved during a hybridization assay using a DNA probe labeled and protected with carbon nanotubes, where better sensitivity was obtained in the detection of $S$. aureus DNA when compared to the same hybridized probe, but without nanotubes. These results have important implications in molecular techniques employed in food samples where DNA probes are easily degraded by cellular enzymes or nucleases present in food. ${ }^{38}$

In another contribution to this area, Karimi et al. ${ }^{121}$ reported in 2019 an aptamer immobilized on multi-walled carbon nanotube (MWCNTs) to detect Bacillus anthracis (Figure 8). Upon the adsorption of the labeled aptamer on MWCNTs, fluorescence emission was quenched. In contrast, by adding the recombinant protective antigen domain 4 (rPAD4) to the hybridization reaction and 

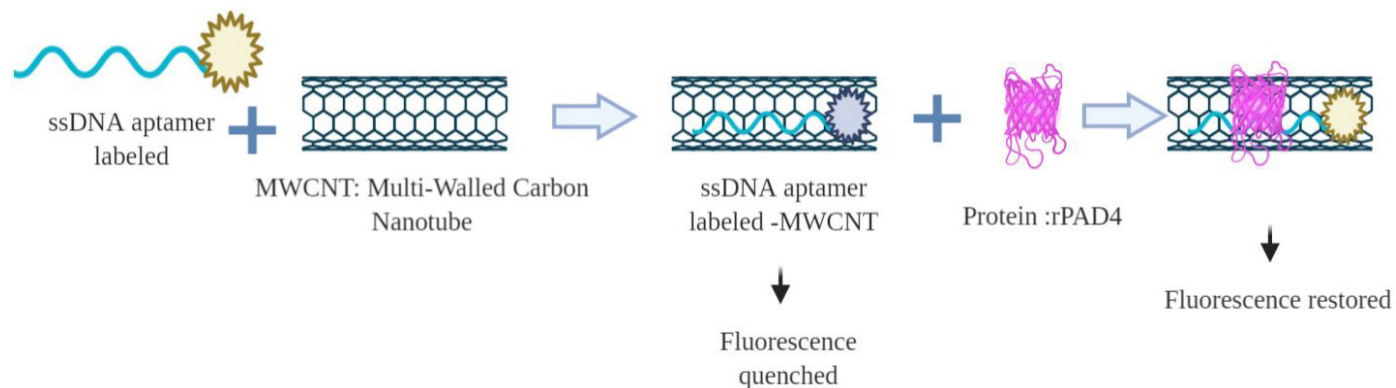

Figure 8. A labeled fluorescent ssDNA aptamer binds to a multi-walled carbon nanotube, which causes its deactivation. When this complex interacts with the rPAd 4 protein, which is a Bacillus anthracis antigen, fluorescence is restored, evidencing the presence of the bacteria (adapted from Karimi et al. ${ }^{121}$ ).

incubation for $10 \mathrm{~min}$, the fluorescence emission was significantly recovered to $85 \%$ as compared to the control.

\subsection{Biosensors with metal-organic frameworks (MOF)}

In recent years, MOF applications, especially nanosized (NMOF), have generated significant interest in biomedicine. Unlike traditional MOFs, NMOFs exhibit highly ordered porosity and inherent pore size but with higher surface areas, which gives them improved biological activity, chemical/colloidal stability, and surface modification facilities. When compared to other nanomaterials, NMOFs demonstrate the following advantages for biomedical applications:

(i) The chemical diversity of MOFs provides a library of versatile porous materials, making them highly available for various applications related to biology.

(ii) The balance between stability and degradability allows reuse and degradation as needed. (iii) Controllable porosity and surface area allow efficient encapsulation/loading of both small molecules and biomacromolecules, providing dispersibility, biocompatibility and biosafety for in vivo applications. ${ }^{122}$

More recently, works such as that of Bhardwaj et al. ${ }^{67}$ using the metallorganic fluorescence framework IRMOF-368 have shown that these MOFs can be used in various biological applications (Figure 9) such as molecular detection, recognition of adenosine triphosphate (ATP) and cancer biomarkers, and in various types of samples, including liquids and gases. ${ }^{67,123}$

The MOF applicability is extensive due to its fascinating framework architecture properties. Several studies have shown that MOFs' chemical nature allows unlimited structural variations during and post-synthesis, which can control the stability of the network, porosity, internal and external surface area, thermal and chemical stability, selectivity, crystal structure, toxicity, and luminescent properties, among others (Table 11). ${ }^{48}$

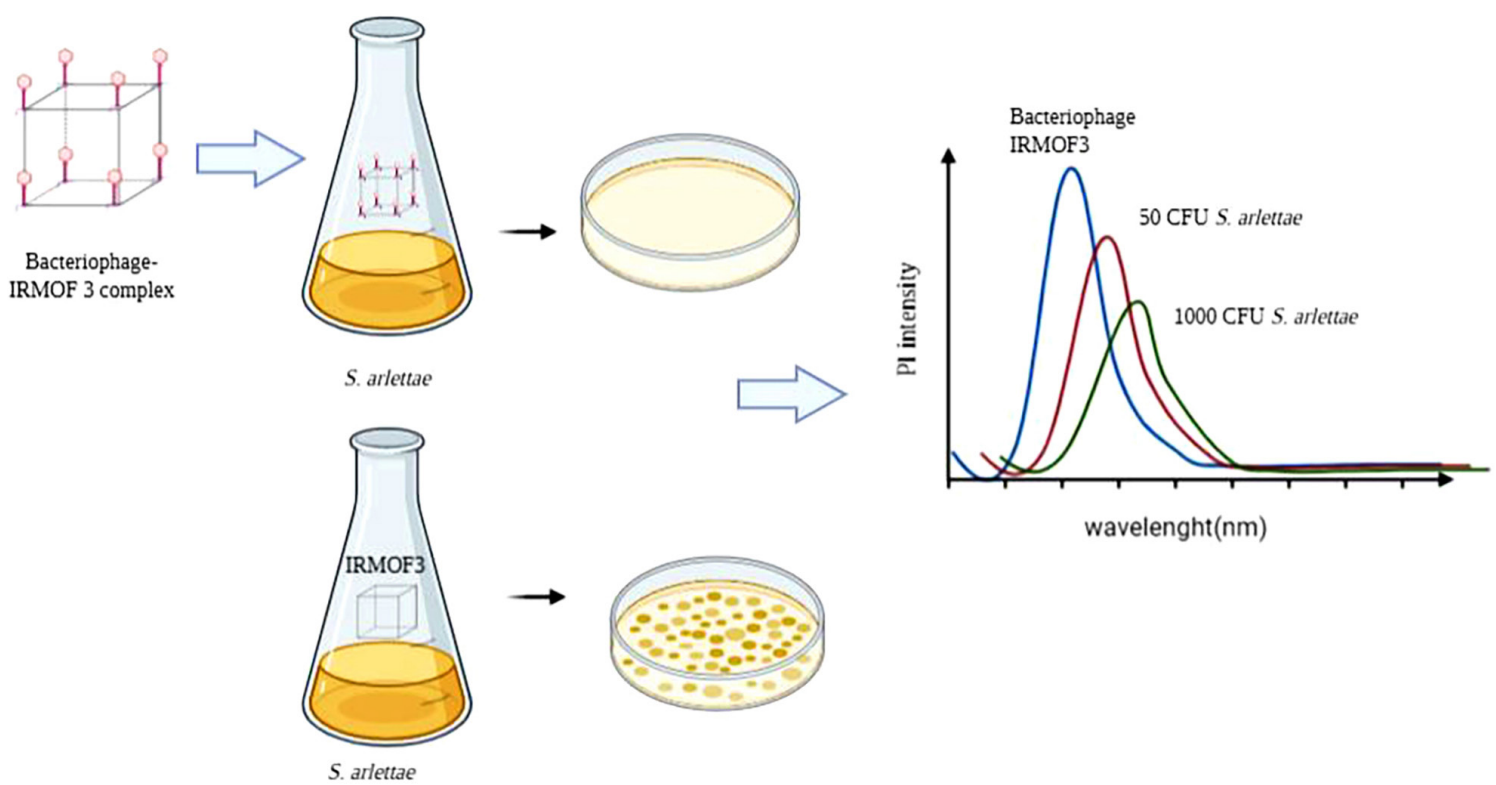

Figure 9. A bacteriophage specific to S. arlettae bioconjugated with a fluorescence metal-organic framework (IRMOF-3) changes its photoluminescence intensity with different bacterial densities (adapted from Bhardwaj et al ${ }^{67}$ ). 
Table 11. Metal-organic frameworks (MOF) used for pathogenic agent detection

\begin{tabular}{|c|c|c|c|c|c|}
\hline $\begin{array}{l}\text { Functionalized } \\
\text { substances }\end{array}$ & $\begin{array}{c}\text { Pathogens or analyte to } \\
\text { detect }\end{array}$ & Operating principle & Limit of detection & $\begin{array}{l}\text { Detection } \\
\text { time / h }\end{array}$ & Reference \\
\hline $\begin{array}{l}\text { Terbium-metal organic } \\
\text { framework Tb(BTC) } \\
\left(\mathrm{H}_{2} \mathrm{O}\right)_{6}(\mathrm{~Tb}-\mathrm{MOF})\end{array}$ & $\begin{array}{c}\text { Bacillus anthracis } \\
\text { (dipicolinic acid DPA } \\
\text { biomarker) }\end{array}$ & $\begin{array}{l}\text { by mixing the fluorescence probe Tb-MOF } \\
\text { with DPA, a rapid reduction in the } \\
\text { photoluminescence signal can be obtained, } \\
\text { maintaining a highly linear relationship with } \\
\text { increasing DPA concentrations }\end{array}$ & $0.04 \mathrm{nmol} \mathrm{L}^{-1}$ & 0.2 & 124 \\
\hline $\mathrm{NH}_{2}-\mathrm{MIL}-53(\mathrm{Fe})$ & Staphylococcus aureus & $\begin{array}{l}\text { the use of glutaraldehyde as a crosslinking } \\
\text { agent allows the conjugation of a MOF with } \\
\text { bacteriophages, obtaining a biosensor that } \\
\text { detects } S \text {. aureus through photoluminescence } \\
\text { extinction }\end{array}$ & $31 \mathrm{CFU} \mathrm{mL}^{-1}$ & 0.3 & 123 \\
\hline $\begin{array}{l}\text { Copper metal-organic } \\
\text { framework nanoparticles } \\
\text { (Cu-MOF-NPs) }\end{array}$ & Escherichia coli & $\begin{array}{l}\mathrm{Cu}-\mathrm{MOF}-\mathrm{NP} \text { improved biological activity } \\
\text { by increasing the dose of particles against } \\
\text { various pathogens (five bacteria strains, } \\
\text { Gram-positive and Gram-negative) compared } \\
\text { to an antibacterial agent }\end{array}$ & $50 \mu \mathrm{g} \mathrm{mL}^{-1}$ & ND & 125 \\
\hline $\begin{array}{l}\text { JXNU-4 } \\
{\left[\left(\mathrm{Me}_{2} \mathrm{NH}_{2}\right)_{2}\left(\mathrm{Zn}_{6}\left(\mu_{4}-\mathrm{O}\right)\right.\right.} \\
\left.(\mathrm{ad})_{4}(\mathrm{BPDC})_{4}\right]_{\mathrm{n}}\end{array}$ & $\begin{array}{c}\text { Bacillus anthracis } \\
\text { (dipicolinic acid DPA } \\
\text { biomarker) }\end{array}$ & $\begin{array}{l}\text { a dual emission hybrid MOF }\left(\mathrm{Tb}^{3+} @ \mathrm{MOF}\right) \\
\text { allowed radiometric detection of DPA; } \\
\text { the formation of the Tb-DPA complex produces } \\
\text { a sensitization of the antenna, increasing the } \\
\text { emission of } \mathrm{Tb}^{3+}\end{array}$ & $3.6 \mathrm{nmol} \mathrm{L}^{-1}$ & 0.2 & 49 \\
\hline Polyaniline (PANI) & $\begin{array}{c}\text { Escherichia coli } \\
\text { O157:H7 }\end{array}$ & $\begin{array}{l}\text { the monitoring and quantification of the } \\
\text { interaction between an aptamer and } E \text {. coli } \\
\text { using methylene blue as an electrochemical } \\
\text { indicator were carried out by differential pulse } \\
\text { voltammetry; } \\
\text { the MB-E. coli } \mathrm{O} 157: \mathrm{H} 7 \text { interaction generates } \\
\text { a signal proportional to the concentration of } \\
\text { E. coli } \mathrm{O} 157: \mathrm{H} 7\end{array}$ & $2 \mathrm{CFU} \mathrm{mL} \mathrm{L}^{-1}$ & 0.3 & 72 \\
\hline $\begin{array}{l}\text { Copper(II) tetrakis } \\
\text { (4-carboxyphenyl) } \\
\text { porphyrin nanosheets } \\
\text { (MOF-NSs) }\end{array}$ & $\begin{array}{c}\text { Salmonella enterica, } \\
\text { Listeria monocytogenes, } \\
\text { and } \\
\text { Vibrio parahemolyticus }\end{array}$ & $\begin{array}{l}\text { the MOF-NSs possess a distinguished affinity } \\
\text { for ssDNA, which causes the labeled DNA's } \\
\text { fluorescence to be quenched; } \\
\text { the labeled duplex is released on binding } \\
\text { to the target pathogen DNA, and the label's } \\
\text { fluorescence is restored }\end{array}$ & $\begin{array}{l}28,35 \text { and } \\
15 \mathrm{pmol} \mathrm{L}^{-1}\end{array}$ & 1 & 69 \\
\hline Aptamer and DNA & $\begin{array}{c}\text { Pseudomonas } \\
\text { aeruginosa }\end{array}$ & $\begin{array}{c}\text { decomposition of } \mathrm{H}_{2} \mathrm{O}_{2} \text { catalyzed by a } \\
\text { Cu-ZrMOF@ Aptamer@ DNA nanocomposite } \\
\text { acted as a signal probe showing conductivity } \\
\text { changes due to electron transfer during } \\
\text { successful detection }\end{array}$ & $2 \mathrm{CFU} \mathrm{mL} \mathrm{L}^{-1}$ & 2 & 85 \\
\hline Antibodies & Staphylococcus aureus & $\begin{array}{l}\text { an antibody-conjugated bioprobe } \\
\text { (Ab/ } \mathrm{NH}_{2}-\mathrm{MIL}-53 \text { ) incubated with varying } \\
\text { concentrations of Staphylococcus aureus } \\
\text { maintained a strong inverse correlation in which } \\
\text { the decrease in fluorescence intensity was } \\
\text { accompanied by an increase in bacterial count }\end{array}$ & $85 \mathrm{CFU} \mathrm{mL}^{-1}$ & ND & 126 \\
\hline Polyaniline (PANI) & Escherichia coli & $\begin{array}{c}\text { a biosensor electrode was developed by } \\
\text { conjugating anti- } E \text {. coli antibodies and } \\
\mathrm{Cu}_{3}(\mathrm{BTC})_{2}-\mathrm{PANI} \text { on an indium-tin-oxide } \\
\text { substrate; } \\
\text { this biosensor allowed detection of very low } \\
\text { concentrations of } E \text {. coli using electrochemical } \\
\text { impedance spectroscopy }\end{array}$ & $2 \mathrm{CFU} \mathrm{mL} \mathrm{m}^{-1}$ & 2 & 88 \\
\hline
\end{tabular}

DPA: docosapentaenoic acid; CFU: colony-forming unit; ND: not determined; BTC: 1,3,5-benzenetricarboxylic acid; BPDC: biphenyl-4,4'-dicarboxylic acid; ssDNA: single-stranded DNA; BTC: benzene-1,3,5-tricarboxylic acid.

\section{Discussion}

Nanobiosensors are new devices that improve traditional biosensors' effectiveness due to the use of nanomaterials in their manufacturing. The development of these devices has allowed the detection of pathogens or some of their components in a fast, efficient, and highly sensitive way in different samples. This has practical implications in the 
clinical field, food industry, and the environmental area. By implementing this type of technology, up to 1 cell $\mathrm{mL}^{-1}$ of the analyzed sample can be detected..$^{25}$

This technology has been widely used to detect pathogens, thanks to the use of some recognition elements present on their surface that function as markers, or the presence of genetic material that can hybridize specifically with designed probes anchored on the nanomaterial. In the development of these devices, aptamers have also been used as new functionalizing molecules. Based on nucleic acids, these have shown an affinity for some structural characteristics of the pathogen in question, facilitating their detection.

Similarly, the technology has also been used to detect toxins or other secreted substances responsible for infectious diseases through colorimetric tests using various types of nanoparticles, which decreases the cost of conventional tests to detect such substances and lowers the limit of detection. Due to the development of these devices, the processing time, the equipment required, and the trained personnel to perform tests for pathogens that compromise public health are reduced.

The most significant number of detection studies are related to Escherichia coli, Staphylococcus aureus, and Salmonella typhimurium. However, the most used microorganism in screening tests has been $E$. coli, which is a bacterium of great importance because it is considered an indicator of fecal contamination in waters, and it is recognized as a cause of diseases such as gastroenteritis, urinary tract infections, and meningitis.

On the other hand, QDs have been primarily used to detect different types of pathogens, such as Cryptosporidium parvum and Giardia lamblia, two species of protozoa present in water samples and which are also recognized as indicators of fecal contamination. ${ }^{89}$ This type of detection test could expand this technology area since it could be applied not only to bacteria but to other organisms of environmental concern. It should also be noted that it would be interesting to verify these detection devices' effectiveness in other areas such as agriculture, where very little has been done.

Each type of nanobiosensors has advantages and disadvantages. It is not easy to define which type of nanobiosensor is more useful for each specific case since there are a variety of devices with multiple principles of operation, those based on nucleic acids, those based on the detection of specific proteins, or those that detect the organism of interest as such. All of the above makes a possible comparison between them more complicated.

To define the effectiveness of this type of device, criteria such as type of bioreceptor, transduction system used, limit and time of detection, and ease of scaling must be considered. It can be seen after carrying out the review that most of the biological and non-biological interactions used as a basis for the design of nanobiosensors are based on antigen-antibody binding, electrostatic interactions, and streptavidin-biotin interaction. Nanobiosensors also use the affinity that specific proteins, such as concanavilin A and lectins, show for carbohydrates present in pathogens' cell walls, which can be used as target molecules. As for the most widely used transduction systems for nanobiosensors, the electrical and optical types stand out.

The limit of detection must also be taken into account to define the device's effectiveness. These data can usually be reported in different units depending on the type of nanobiosensor, though, in general, it is evident by this review that the best limit of detection for a nanobiosensor based on silica nanoparticles is 1 cell $\mathrm{mL}^{-1}$ of sample. ${ }^{25}$ However, several nanobiosensors based on metallic nanoparticles, specifically on AuNPs, also show outstanding limit of detection, detecting 10 bacteria $\mathrm{mL}^{-1}$ of sample. This indicates that efforts should be directed to improve the design of devices based on metallic nanoparticles, not only because of the limit of detection they present but also because they require fewer chemical precursors for their elaboration, making them the simplest to build and the less expensive.

The above also shows the currently growing interest in developing green chemistry methodologies, where live species are used, including bacteria, fungi, or plants, to obtain nanoparticles. These approaches could replace traditional nanoparticles synthesized using toxic chemical precursors, and then, we would have nanobiosensors composed of nanoparticles obtained through biosynthesis, making the technology more feasible for commercial use, specifically in the food industry.

Additionally, it is essential to highlight a novel approach within this technology, the design of hybrid nanobiosensors, where different types of nanomaterials are used to make the detection process more efficient. In this field, the use of magnetic nanoparticles fused with titanium dioxide nanocrystals or quantum dots to detect various types of bacterial and fungal pathogens appears to be the most promising technology.

\section{Conclusion}

The application of nanotechnology to detect pathogenic microorganisms has led to significant advances, reaching limit of detection of up to 1 cell $\mathrm{mL}^{-1}$ of sample, requiring only minutes to perform the detection, and using techniques as simple as UV spectroscopy. Furthermore, nanotechnology's advantages predict that we will continue 
to reduce limit of detection, analysis time, and instrumental requirements. This makes it possible to foresee that we are very close to the commercialization of portable nanosensors for on-site application in agroindustry, food, and human health. However, the specificity shown by the currently reported works and the increasingly recurrent appearance of pathogens in humans and animals possibly show us the need to develop nanostructured systems with the ability to detect multiple pathogenic microorganisms at the same time, an area until now unexplored.

\section{Acknowledgments}

A very special thanks to my friend and colleague, Christopher J. Thompson, PhD, Director of Business Development at BrightSpec, for the revision of the text, corrections and comments. To the government of Boyaca through the announcement of high-level human capital for the Department of Boyaca 2015 and to the Ministry of Science, Technology and Innovation of Colombia for the financing of the PhD scholarship.

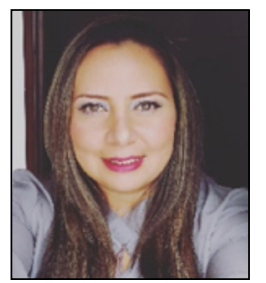

Mayra Beltrán-Pineda was born in Tunja-Boyacá, graduated as a Biologist from the Universidad Pedagógica y Tecnológica de Colombia in 2004. She was a young researcher at COLCIENCIAS in 2006.

She obtained her Master's degree in Sciences-Microbiology in 2009 from the Universidad Nacional de Colombia. Her research area is environmental microbiology, biotechnology, and nanotechnology. She is currently a PhD student in Biotechnology from the Universidad Nacional de Colombia under the supervision of Professor Cesar Sierra in the area of nanobiotechnology. Her doctoral research is focused on the biosynthesis of silver nanoparticles for the control of a potato plant pathogen.

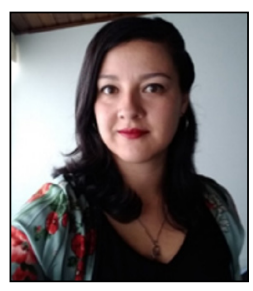

Diana C. Peña-Solórzano was born in Calarcá, Quindío, and graduated in Chemistry from the Universidad Nacional of Colombia (2011). She obtained a double doctoral degree from the Universidad Nacional of Colombia and Regensburg University in Germany (2017). She held a postdoctoral degree at Universidad Nacional of Colombia (2019). Her research interests are in organic chemistry with applications in medicine, including the synthesis, characterization, and inhibitory activity evaluation of new analogs of tariquidar on breast cancer resistance protein (ABCG2). She is also interested in the development of eutectic solvents based on zinc chloride for green chemistry in the synthesis of tetrahydroquinolines, imidazoles, benzimidazole, and others.

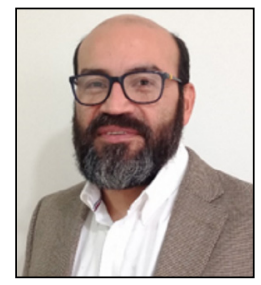

Cesar A. Sierra studied chemistry at the Universidad Industrial de Santander-Colombia and obtained his PhD in 2005 with Prof Paul Lahti at the University of Massachusetts, Amherst. Upon returning to his native country, he established the research group on macromolecules, and currently acts as head of the Chemistry Department at the Universidad Nacional de Colombia. The implementation of nanotechnology in packaging, sensors, and textiles is within his current research interests, taking the results obtained until his incorporation in innovative Colombian companies, where he is exploring his facet as an entrepreneur.

\section{References}

1. Jyoti, A.; Tomar, R. S.; Environ. Chem. Lett. 2017, 15, 1.

2. Bej, A. K.; Mahbubani, M. H.; PCR Methods Appl. 1992, 1, 151.

3. Fang, Y.; Ramasamy, R. P.; Biosensors 2015, 5, 537.

4. Volpi, E. V.; Bridger, J. M.; Biotechniques 2008, 45, 385.

5. Ma, H.; Shieh, K.-J.; Lee, S.-L.; Nature 2006, 4, 36.

6. Mohan, K.; Pai, S.; Rao, R.; Sripathi, H.; Prabhu, S.; Indian J. Dermatol. Venereol. Leprol. 2008, 74, 415.

7. Brown, M.; Wittwer, C.; Clin. Chem. 2000, 46, 1221.

8. Craw, P.; Balachandran, W.; Lab Chip 2012, 12, 2469; Kokkinos, P.; Ziros, P.; Bellou, M.; Vantarakis, A.; Food Anal. Methods 2014, 7, 512 .

9. Silbert, L.; Ben Shlush, I.; Israel, E.; Porgador, A.; Kolusheva, S.; Jelinek, R.; Appl. Environ. Microbiol. 2006, 72, 7339; Mura, S.; Greppi, G.; Marongiu, M. L.; Roggero, P. P.; Ravindranath, S. P.; Mauer, L. J.; Schibeci, N.; Perria, F.; Piccinini, M.; Innocenzi, P.; Beilstein J. Nanotechnol. 2012, 3, 485.

10. Gilmartin, N.; O’Kennedy, R.; Enzyme Microb. Technol. 2012, $50,87$.

11. Driskell, J.; Tripp, R.; Clin. Microbiol. Newsl. 2009, 31, 137.

12. Kaittanis, C.; Santra, S.; Perez, J. M.; Adv. Drug Delivery Rev. 2010, 62, 408.

13. Bhardwaj, N.; Bhardwaj, S. K.; Nayak, M. K.; Mehta, J.; Kim, K.-H.; Deep, A.; TrAC, Trends Anal. Chem. 2017, 97, 120.

14. Zhao, X.; Hilliard, L. R.; Mechery, S. J.; Wang, Y.; Bagwe, R. P.; Jin, S.; Tan, W.; Proc. Natl. Acad. Sci. U. S. A. 2004, 101, 15027.

15. Khot, L. R.; Sankaran, S.; Maja, J. M.; Ehsani, R.; Schuster, E. W.; Crop Prot. 2012, 35, 64. 
16. Xu, K.; Huang, J.; Ye, Z.; Ying, Y.; Li, Y.; Sensors 2009, 9, 5534.

17. Lin, P.-C.; Lin, S.; Wang, P. C.; Sridhar, R.; Biotechnol. Adv. 2014, 32, 711.

18. Ho, K.-C.; Tsai, P.-J.; Lin, Y.-S.; Chen, Y.-C.; Anal. Chem. 2004, 76,7162 .

19. Nath, S.; Kaittanis, C.; Tinkham, A.; Perez, J. M.; Anal. Chem. 2008, 80, 1033 .

20. Zhang, D.; Carr, D. J.; Alocilja, E. C.; Biosens. Bioelectron. 2009, 24, 1377.

21. Sahoo, A. K.; Sharma, S.; Chattopadhyay, A.; Ghosh, S. S.; Nanoscale 2012, 4, 1688.

22. Zhou, H.; Yang, D.; Ivleva, N. P.; Mircescu, N. E.; Niessner, R.; Haisch, C.; Anal. Chem. 2014, 86, 1525.

23. Tanvir, F.; Yaqub, A.; Tanvir, S.; Anderson, W. A.; Enzyme Microb. Technol. 2017, 99, 49.

24. Verma, P.; Maheshwari, S. K.; Int. J. Nano Dimens. 2019, 10, 18.

25. Thepwiwatjit, N.; Thattiyaphong, A.; Limsuwan, P.; Tuitemwong, K.; Tuitemwong, P.; J. Nanomater. 2013, 2013, 92.

26. Chitra, K.; Annadurai, G.; J. Nanotechnol. 2013, ID 509628.

27. Lin, Y.-S.; Tsai, P.-J.; Weng, M.-F.; Chen, Y.-C.; Anal. Chem. 2005, 77, 1753.

28. Ileš, D.; Martinović, G.; Kozak, D.; Strojarstvo 2011, 53, 127.

29. Tully, E.; Hearty, S.; Leonard, P.; O’Kennedy, R.; Int. J. Biol. Macromol. 2006, 39, 127.

30. Dai, H.; Acc. Chem. Res. 2002, 35, 1035.

31. Bon, V.; Senkovska, I.; Kaskel, S. In Nanoporous Materials for Gas Storage; Kaneko, K.; Rodríguez-Reinoso, F., eds.; Springer: Singapore, 2019, p. 137; Robin, A. Y.; Fromm, K M.; Coord. Chem. Rev. 2006, 250, 2127; Stock, N.; Biswas, S.; Chem. Rev. 2011, 112, 933.

32. Bhui, D. K.; Bar, H.; Sarkar, P.; Sahoo, G. P.; De, S. P.; Misra, A.; J. Mol. Liq. 2009, 145, 33; Desai, R.; Mankad, V.; Gupta, S. K.; Jha, P. K.; Nanosci. Nanotechnol. Lett. 2012, 4, 30; Ingham, B.; Crystallogr. Rev. 2015, 21, 229; Stephen Inbaraj, B.; Chen, B. H.; J. Food Drug Anal. 2016, 24, 15.

33. Bhattacharya, K.; Mukherjee, S. P.; Gallud, A.; Burkert, S. C.; Bistarelli, S.; Bellucci, S.; Bottini, M.; Star, A.; Fadeel, B.; Nanomedicine 2016, 12, 333.

34. Vo-Dinh, T.; Cullum, B.; Fresenius' J. Anal. Chem. 2000, 366, 540.

35. Byrne, B.; Stack, E.; Gilmartin, N.; O’Kennedy, R.; Sensors 2009, 9, 4407.

36. Jianrong, C.; Yuqing, M.; Nongyue, H.; Xiaohua, W.; Sijiao, L.; Biotechnol. Adv. 2004, 22, 505.

37. Mathelié-Guinlet, M.; Gammoudi, I.; Beven, L.; Moroté, F.; Delville, M.-H.; Grauby-Heywang, C.; Cohen-Bouhacina, T.; Procedia Eng. 2016, 168, 1048.

38. Tang, X.; Bansaruntip, S.; Nakayama, N.; Yenilmez, E.; Chang, Y.-1.; Wang, Q.; Nano Lett. 2006, 6, 1632.
39. Wen, C.-Y.; Hu, J.; Zhang, Z.-L.; Tian, Z.-Q.; Ou, G.-P.; Liao, Y.-L.; Li, Y.; Xie, M.; Sun, Z.-Y.; Pang, D.-W.; Anal. Chem. 2013, 85, 1223.

40. Chen, C.; Wang, Q.; Am. J. Nano Res. Appl. 2015, 3, 13.

41. Chattopadhyay, S.; Sabharwal, P. K.; Jain, S.; Kaur, A.; Singh, H.; Anal. Chim. Acta 2019, 1067, 98.

42. Dong, X.; Shi, Z.; Xu, C.; Yang, C.; Chen, F.; Lei, M.; Wang, J.; Cui, Q.; Biosens. Bioelectron. 2020, 149, 111843.

43. El-Boubbou, K.; Gruden, C.; Huang, X.; J. Am. Chem. Soc. 2007, 129, 13392.

44. Dogra, N.; Li, X.; Kohli, P.; Langmuir 2012, 28, 12989.

45. Phillips, R. L.; Miranda, O. R.; You, C. C.; Rotello, V. M.; Bunz, U. H.; Angew. Chem. 2008, 47, 2590.

46. Villamizar, R. A.; Maroto, A.; Rius, F. X.; Inza, I.; Figueras, M. J.; Biosens. Bioelectron. 2008, 24, 279.

47. Abdeen, S.; Isaac, R. R.; Geo, S.; Sornalekshmi, S.; Rose, A.; Praseetha, P.; Nano Biomed. Eng. 2013, 5, 39; Alghuthaymi, M. A.; Almoammar, H.; Rai, M.; Said-Galiev, E.; Abd-Elsalam, K. A.; Biotechnol. Biotechnol. Equip. 2015, 29, 221.

48. Kumar, P.; Deep, A.; Kim, K.-H.; TrAC, Trends Anal. Chem. 2015, 73, 39.

49. Zhang, D.; Zhou, Y.; Cuan, J.; Gan, N.; CrystEngComm 2018, 20, 1264.

50. Ardekani, S. M.; Dehghani, A.; Ye, P.; Nguyen, K.-A.; Gomes, V. G.; J. Colloid Interface Sci. 2019, 552, 378.

51. Mathelié-Guinlet, M.; Cohen-Bouhacina, T.; Gammoudi, I.; Martin, A.; Béven, L.; Delville, M.-H.; Grauby-Heywang, C.; Sens. Actuators, B 2019, 292, 314.

52. Mou, X.-Z.; Chen, X.-Y.; Wang, J.; Zhang, Z.; Yang, Y.; Shou, Z.-X.; Tu, Y.-X.; Du, X.; Wu, C.; Zhao, Y.; ACS Appl. Mater. Interfaces 2019, 11, 23093.

53. Suaifan, G. A.; Zourob, M.; Microchim. Acta 2019, 186, 230.

54. Yu, S.; Tang, Y.; Yan, M.; Aguilar, Z. P.; Lai, W.; Xu, H.; Sens. Actuators, B 2019, 279, 31.

55. Murasova, P.; Kovarova, A.; Kasparova, J.; Brozkova, I.; Hamiot, A.; Pekarkova, J.; Dupuy, B.; Drbohlavova, J.; Bilkova, Z.; Korecka, L.; J. Electroanal. Chem. 2020, 114051.

56. Huang, Y.-F.; Wang, Y.-F.; Yan, X.-P.; Environ. Sci. Technol. 2010, 44, 7908.

57. Edgar, R.; McKinstry, M.; Hwang, J.; Oppenheim, A. B.; Fekete, R. A.; Giulian, G.; Merril, C.; Nagashima, K.; Adhya, S.; Proc. Natl. Acad. Sci. U. S. A. 2006, 103, 4841.

58. Mukhopadhyay, B.; Martins, M. B.; Karamanska, R.; Russell, D. A.; Field, R. A.; Tetrahedron Lett. 2009, 50, 886.

59. Guven, B.; Basaran-Akgul, N.; Temur, E.; Tamer, U.; Boyac1, İ. H.; Analyst 2011, 136, 740.

60. Maurer, E. I.; Comfort, K. K.; Hussain, S. M.; Schlager, J. J.; Mukhopadhyay, S. M.; Sensors 2012, 12, 8135.

61. Gasparyan, V. K.; Bazukyan, I. L.; Anal. Chim. Acta 2013, 766, 83. 
62. Petaccia, M.; Bombelli, C.; Paroni Sterbini, F.; Papi, M.; Giansanti, L.; Bugli, F.; Sanguinetti, M.; Mancini, G.; Sens. Actuators, B 2017, 248, 247.

63. Villamizar, R. A.; Maroto, A.; Rius, F. X.; Sens. Actuators, B 2009, 136, 451.

64. García-Aljaro, C.; Cella, L. N.; Shirale, D. J.; Park, M.; Muñoz, F. J.; Yates, M. V.; Mulchandani, A.; Biosens. Bioelectron. 2010 , 26,1437

65. Chen, L.; Zhang, J.; J. Biosens. Bioelectron. 2012, S11, 005.

66. Thuy, N. T.; Tam, P. D.; Tuan, M. A.; Le, A.-T.; Van Thu, V.; Van Hieu, N.; Chien, N. D.; Curr. Appl. Phys. 2012, 12, 1553.

67. Bhardwaj, N.; Bhardwaj, S. K.; Mehta, J.; Nayak, M. K.; Deep, A.; New J. Chem. 2016, 40, 8068.

68. Muniandy, S.; Teh, S. J.; Thong, K. L.; Thiha, A.; Dinshaw, I. J.; Lai, C. W.; Ibrahim, F.; Leo, B. F.; Crit. Rev. Anal. Chem. 2019, 49, 510 .

69. Qiu, Q.; Chen, H.; Ying, S.; Sharif, S.; You, Z.; Wang, Y.; Ying, Y.; Microchim. Acta 2019, 186, 93.

70. You, Z.; Qiu, Q.; Chen, H.; Feng, Y.; Wang, X.; Wang, Y.; Ying, Y.; Biosens. Bioelectron. 2020, 150, 111896.

71. Wang, B.; Huang, X.; Ma, M.; Shi, Q.; Cai, Z.; Food Control. 2014, 35, 26.

72. Shahrokhian, S.; Ranjbar, S.; Analyst 2018, 143, 3191.

73. Sobhan, A.; Lee, J.; Park, M.-K.; Oh, J.-H.; LWT 2019, 108, 48.

74. Chen, X.; Tang, M.; Liu, Y.; Huang, J.; Liu, Z.; Tian, H.; Zheng, Y.; de la Chapelle, M. L.; Zhang, Y.; Fu, W.; Microchim. Acta 2019, 186, 102.

75. Carrillo-Carrión, C.; Simonet, B. M.; Valcárcel, M.; Biosens. Bioelectron. 2011, 26, 4368.

76. Chunglok, W.; Wuragil, D. K.; Oaew, S.; Somasundrum, M.; Surareungchai, W.; Biosens. Bioelectron. 2011, 26, 3584.

77. Joo, J.; Yim, C.; Kwon, D.; Lee, J.; Shin, H. H.; Cha, H. J.; Jeon, S.; Analyst 2012, 137, 3609.

78. Zelada-Guillén, G. A.; Sebastián-Avila, J. L.; Blondeau, P.; Riu, J.; Rius, F. X.; Biosens. Bioelectron. 2012, 31, 226.

79. Yaohua, H.; Chengcheng, W.; Bing, B.; Mintong, L.; Wang, R.; Li, Y.; Int. J. Agric. Biol. Eng. 2014, 7, 77.

80. Xue, L.; Huang, F.; Hao, L.; Cai, G.; Zheng, L.; Li, Y.; Lin, J.; Food Chem. 2020, 126719.

81. Zhong, M.; Yang, L.; Yang, H.; Cheng, C.; Deng, W.; Tan, Y.; Xie, Q.; Yao, S.; Biosens. Bioelectron. 2019, 126, 493.

82. Wu, S.; Duan, N.; Shen, M.; Wang, J.; Wang, Z.; Microchim. Acta 2019, 186, 401.

83. Banasiuk, R.; Krychowiak, M.; Swigon, D.; Tomaszewicz, W.; Michalak, A.; Chylewska, A.; Ziabka, M.; Lapinski, M.; Koscielska, B.; Narajczyk, M.; Arabian J. Chem. 2020, 13, 1415.

84. Wang, Q.-Y.; Kang, Y.-J.; Nanoscale Res. Lett. 2016, 11, 150.

85. Zhang, X.; Xie, G.; Gou, D.; Luo, P.; Yao, Y.; Chen, H.; Biosens. Bioelectron. 2019, 142, 111486.
86. Sun, J.; Ji, J.; Sun, Y.; Abdalhai, M. H.; Zhang, Y.; Sun, X.; Biosens. Bioelectron. 2015, 70, 239.

87. Liu, F.; Choi, K. S.; Park, T. J.; Lee, S. Y.; Seo, T. S.; BioChip J. 2011, 5, 123.

88. Gupta, A.; Bhardwaj, S. K.; Sharma, A. L.; Kim, K.-H.; Deep, A.; Environ. Res. 2019, 171, 395.

89. Zhu, L.; Ang, S.; Liu, W.-T.; Appl. Environ. Microbiol. 2004, $70,597$.

90. Chen, W.-J.; Tsai, P.-J.; Chen, Y.-C.; Anal. Chem. 2008, 80, 9612.

91. Naimushin, A. N.; Soelberg, S. D.; Nguyen, D. K.; Dunlap, L.; Bartholomew, D.; Elkind, J.; Melendez, J.; Furlong, C. E.; Biosens. Bioelectron. 2002, 17, 573.

92. Lin, D.; Pillai, R. G.; Lee, W. E.; Jemere, A. B.; Microchim. Acta 2019, 186, 169.

93. Khater, M.; Escosura-Muñiz, A.; Altet, L.; Merkoçi, A.; Anal. Chem. 2019, 91, 4790 .

94. Bai, L.; Chen, Y.; Liu, X.; Zhou, J.; Cao, J.; Hou, L.; Guo, S.; Anal. Chim. Acta 2019, 1080, 75.

95. Elkhawaga, A. A.; Khalifa, M. M.; El-Badawy, O.; Hassan, M. A.; El-Said, W. A.; PloS One 2019, 14, e0216438.

96. Du, J.; Wu, S.; Niu, L.; Li, J.; Zhao, D.; Bai, Y.; Anal. Methods 2020, 12, 212.

97. Satpathy, G.; Chandra, G. K.; Manikandan, E.; Mahapatra, D. R.; Umapathy, S.; Biotechnol. Lett. 2020, 42, 853.

98. Chen, H.; Park, S.-G.; Choi, N.; Moon, J.-I.; Dang, H.; Das, A.; Lee, S.; Kim, D.-G.; Chen, L.; Choo, J.; Biosens. Bioelectron. 2020, 167, 112496.

99. Singh, P.; Kakkar, S.; Kumar, R.; Bhalla, V.; Chem. Commun. 2019, 55, 4765.

100. Shah, S.; Gaikwad, S.; Nagar, S.; Kulshrestha, S.; Vaidya, V.; Nawani, N.; Pawar, S.; Biofouling 2019, 35, 34.

101. Hurley, M. T.; Wang, Z.; Mahle, A.; Rabin, D.; Liu, Q.; English, D. S.; Zachariah, M. R.; Stein, D.; DeShong, P.; Adv. Funct. Mater. 2013, 23, 3335.

102. Mathew, F. P.; Alocilja, E. C.; Biosens. Bioelectron. 2005, 20 , 1656.

103. He, X.; Hu, C.; Guo, Q.; Wang, K.; Li, Y.; Shangguan, J.; Biosens. Bioelectron. 2013, 42, 460.

104. Rajendran, V. K.; Bakthavathsalam, P.; Ali, B. M. J.; Microchim. Acta 2014, 181, 1815.

105. Jiang, Y.; Xu, Y.; Wang, R.; Zhao, B.; Zhang, X.; Zhao, H.; RSC Adv. 2015, 5, 54338.

106. Shams, A.; Rahimian Zarif, B.; Salouti, M.; Shapouri, R.; Mirzaii, S.; Artif. Cells, Nanomed., Biotechnol. 2019, 47, 2562.

107. Gu, Z.; Fu, A.; Ye, L.; Kuerban, K.; Wang, Y.; Cao, Z.; ACS Sens. 2019, 4, 2922.

108. Dong, X.-m.; Jing, T.; Li, T.-t.; Zhang, P.; Yan, Z.; Yu, T.; Su, R.-h.; Shi, D.-f.; J. Integr. Agric. 2019, 18, 1936.

109. Rispail, N.; de Matteis, L.; Santos, R.; Miguel, A. S.; Custardoy, L.; Testillano, P. S.; Risueño, M. C.; Pérez-de-Luque, A.; 
Maycock, C.; Fevereiro, P.; Oliva, A.; Fernández-Pacheco, R.; Ibarra, M. R.; de la Fuente, J. M.; Marquina, C.; Rubiales, D.; Prats, E.; ACS Appl. Mater. Interfaces 2014, 6, 9100.

110. Suaifan, G. A.; Alhogail, S.; Zourob, M.; Biosens. Bioelectron. 2017, 92, 702 .

111. Zou, D.; Jin, L.; Wu, B.; Hu, L.; Chen, X.; Huang, G.; Zhang, J.; Int. Dairy J. 2019, 91, 82.

112. Martínez-Matamoros, D.; Castro-García, S.; Balado, M.; Matamoros-Veloza, A.; Camargo-Valero, M. A.; Cespedes, O.; Rodríguez, J.; Lemos, M. L.; Jiménez, C.; RSC Adv. 2019, 9, 13533.

113. Yang, L.; Li, Y.; J. Food Prot. 2005, 68, 1241.

114. Wu, S. M.; Zhao, X.; Zhang, Z. L.; Xie, H. Y.; Tian, Z. Q.; Peng, J.; Lu, Z. X.; Pang, D. W.; Xie, Z. X.; ChemPhysChem 2006, 7, 1062.

115. Wang, H.; Li, Y.; Wang, A.; Slavik, M.; J. Food Prot. 2011, 74, 2039.

116. Jackeray, R.; Zainul Abid, C. K. V.; Singh, G.; Jain, S.; Chattopadhyaya, S.; Sapra, S.; Shrivastav, T. G.; Singh, H.; Talanta 2011, 84, 952.
117. Wang, R.; Xu, Y.; Zhang, T.; Jiang, Y.; Anal. Methods 2015, 7, 1701.

118. Elkin, T.; Jiang, X.; Taylor, S.; Lin, Y.; Gu, L.; Yang, H.; Brown, J.; Collins, S.; Sun, Y. P.; ChemBioChem 2005, 6, 640.

119. Gu, L.; Elkin, T.; Jiang, X.; Li, H.; Lin, Y.; Qu, L.; Tzeng, T.-R. J.; Joseph, R.; Sun, Y.-P.; Chem. Commun. 2005, 874.

120. Yang, M.; Peng, Z.; Ning, Y.; Chen, Y.; Zhou, Q.; Deng, L.; Sensors 2013, 13, 6865.

121. Karimi, F.; Dabbagh, S.; Int. J. Biol. Macromol. 2019, 140, 842.

122. Yang, J.; Yang, Y. W.; Small 2020, 16, 1906846.

123. Bhardwaj, N.; Bhardwaj, S. K.; Mehta, J.; Kim, K.-H.; Deep, A.; ACS Appl. Mater. Interfaces 2017, 9, 33589.

124. Bhardwaj, N.; Bhardwaj, S.; Mehta, J.; Kim, K.-H.; Deep, A.; Biosens. Bioelectron. 2016, 86, 799.

125. Sheta, S. M.; El-Sheikh, S. M.; Abd-Elzaher, M. M.; Dalton Trans. 2018, 47, 4847.

126. Bhardwaj, N.; Bhardwaj, S. K.; Bhatt, D.; Tuteja, S. K.; Kim, K.-H.; Deep, A.; Anal. Methods 2019, 11, 917.

Submitted: May 16, 2021 Published online: June 1, 2021 